\title{
Eosinophilic and Noneosinophilic Asthma
}

\author{
Tara F. Carr ${ }^{1 *}$, Amir A. Zeki ${ }^{2 \star}$, and Monica Kraft ${ }^{1}$ \\ ${ }^{1}$ Division of Pulmonary, Allergy, Critical Care, and Sleep Medicine, Department of Medicine, University of Arizona, Tucson, Arizona; \\ and ${ }^{2}$ Division of Pulmonary, Critical Care, and Sleep Medicine, Department of Internal Medicine, University of California Davis School of \\ Medicine, Davis, California
}

The term "eosinophilic" asthma (EA) generally refers to the clinical inflammatory phenotype of asthma wherein a significant number of sputum, airway, and/or blood eosinophils are present. Conversely, individuals with "noneosinophilic" asthma (NEA) may still demonstrate low numbers of eosinophils, but the dominant inflammatory cell type may include neutrophils, mixed granulocyte inflammatory cells, or very few inflammatory cells, termed paucigranulocytic inflammation. Although the mechanisms driving EA are becoming clearer, by contrast much less attention has been given to the underlying mechanisms that drive NEA, leading to a lack of available therapies for this patient population.

Although "phenotype" refers to the observable characteristics of disease in an individual, by "endotypes" we mean the specific biological mechanism that causes those observed properties of any given phenotype. Understanding the manifold mechanisms or endotypes contributing to EA and NEA and the resulting clinical phenotypes derived from these endotypes will lead to novel treatment options and provide an opportunity for more precise and tailored treatments. This review highlights the mechanisms currently believed to underlie the recognized subphenotypes of EA and NEA and briefly discusses their clinical presentations as well as implications for treatment.

\section{Definition of Eosinophilic and Noneosinophilic Asthma}

Asthma can be broadly classified as eosinophilic or noneosinophilic on the basis of airway or peripheral blood cellular profiles, with approximately half of individuals with asthma falling into each category (1-5). Sputum cellular profiles are believed to directly reflect lung inflammation and therefore are the preferred method used in asthma research to determine EA (6). Sputum eosinophils should be reported as a percentage of total cells from either a whole expectorate or sputum plug. Sputum eosinophil levels of greater than 2 to $3 \%$ have been used to define EA (7). However, technical requirements for sputum processing and cell counting may limit the feasibility of using sputum eosinophil counts in all clinical centers.

Eosinophils may also be detected in bronchial wall biopsies. Bronchial wall biopsy samples must be obtained via bronchoscopy, which, as a relatively invasive procedure, is not routinely performed in patients with asthma outside of the research setting. There is no actual cutoff for numbers of eosinophils in the airway wall that defines EA per se. Wenzel and colleagues demonstrated two distinct phenotypes on the basis of presence or absence of bronchial wall eosinophils in a severe asthma cohort, wherein those subjects with asthma with eosinophils demonstrated an average of 20 eosinophils $/ \mathrm{mm}^{2}$ of tissue (interquartile range, 16-31 eosinophils/mm²) (5). In 2007, Berry and colleagues described compartmental inflammatory characteristics of asthma in a group of patients not using controller therapy. In the group of patients with EA, defined as sputum eosinophils greater than $2 \%$, bronchoalveolar wash eosinophil count was $2.0 \%$ (geometric mean, 0.2), and the mean number of submucosal eosinophils detected was 23 eosinophils $/ \mathrm{mm}^{2}$ (interquartile range distance, 29 eosinophils $/ \mathrm{mm}^{2}$ ) (8). Supporting the use of these findings as endotypically meaningful, Jia and colleagues compared serum periostin, a biomarker produced by airway epithelial cells and shown to be elevated in T-helper 2 or type 2 (Th2/T2) asthma (9), to sputum and lower airway eosinophils (10). They demonstrated that serum periostin was significantly elevated in subjects with asthma who demonstrated airway wall eosinophilia (defined as $>22$ eosinophils $/ \mathrm{mm}^{2}$ ) and elevated sputum eosinophils (defined as $>3 \%$ ). However, the use of inhaled corticosteroids, which is first-line therapy for asthma, can blur this classification and reduce eosinophils, as demonstrated by Cowan and colleagues (11).

By comparison, blood eosinophil count is a convenient biomarker, because blood is easy to obtain and cell counting is standardized and/or mechanized in commercial laboratories. However, it is not available as a true point-of-care test, and

(Received in original form November 7, 2016; accepted in final form September 13, 2017)

*These authors contributed equally to this work.

Supported by National Institute of Allergy and Infectious Diseases grant U19125357 (T.F.C. and M.K.) and NIH grants U24 DK097154 and K08 HL114882 (A.A.Z.).

Author Contributions: All authors contributed to conception, design, analysis of data, critical revisions of draft for important intellectual content, and approval of the final version of the manuscript. All authors agree to be accountable for all aspects of the work.

Correspondence and requests for reprints should be addressed to Tara F. Carr, M.D., 1501 North Campbell Avenue, Tucson, AZ85724-5030. E-mail: tcarr@deptofmed. arizona.edu.

Am J Respir Crit Care Med Vol 197, Iss 1, pp 22-37, Jan 1, 2018

Copyright (C) 2018 by the American Thoracic Society

Originally Published in Press as DOI: 10.1164/rccm.201611-2232PP on September 14, 2017

Internet address: www.atsjournals.org 
values can fluctuate over time (12-14). Recently, the recommended range of peripheral blood eosinophilia considered consistent with EA has been derived from pharmacologic studies of biologics that target eosinophils (15-17). The range of peripheral eosinophilia that corresponds to treatment with anti-IL-5 biologics is in the range of 300 to 400 cells/ $\mu$ l, but data also suggest that response to these therapies can be seen with peripheral eosinophils as low as 200 cells/ $\mu$ l (18). Studies of the anti-IL-5 mepolizumab required only peripheral blood eosinophilia greater than or equal to 150 cells/ $\mu$ l at screening or 300 cells/ $\mu$ l in the preceding year $(15,16)$. However, blood eosinophil counts do not necessarily reflect sputum eosinophil counts. For example, Hastie and colleagues showed that sputum and blood eosinophils do not always correlate well, with an $R$ value of 0.19 with approximately $40 \%$ misclassification (19). The extremes of blood eosinophil levels may be more sensitive and specific for identifying sputum eosinophils $(20,21)$. For example, patients with blood eosinophil counts less than 90 cells/ $\mu \mathrm{l}$ are highly unlikely to have airway eosinophilia; alternately, almost all patients with more than 400 cells/ $\mu$ l can be expected to have significant sputum eosinophils (22).

In light of the challenges underlying comprehensive evaluation of compartmentalized eosinophilia, use of other biomarkers in combination with or in lieu of eosinophil counts may help to identify eosinophilic and noneosinophilic disease. For example, sputum and serum periostin levels, which reflect IL-13-related inflammation, are elevated in EA as compared with NEA, and this may also serve to help clinicians distinguish between these two subtypes $(23,24)$. The gene for dipeptidyl peptidase- 4 is also induced by IL-13, expressed by eosinophils (25), and can predict individuals who will benefit from anti-IL-13 treatments for severe asthma (26). The fraction of exhaled nitric oxide may predict sputum eosinophilia (27). Levels of sputum, oropharyngeal, or nasal eosinophil peroxidase correlate strongly with airway eosinophilia in asthma (28) and may signal uncontrolled disease (29). Newer technology, including that of noninvasive exhaled breath analysis (i.e., eNOSE), can also identify lower airway eosinophilia in asthma (30). Although these biomarkers do not yet replace sputum eosinophilia as the gold standard of diagnosis, when and if clinically available they could be used as noninvasive markers of eosinophilic inflammation in asthma.

The lack of eosinophilia, by default, has been used to define NEA $(31,32)$. Those considered to have NEA can be further differentiated into paucigranulocytic ( $<61 \%$ neutrophils), mixed granulocytic, or neutrophilic asthma, with defining values of sputum neutrophilia ranging from as low as $>40 \%$ to as high as $\geqslant 76 \%(33,34)$. Wenzel and colleagues demonstrated that in a cohort of subjects with severe asthma receiving high-dose inhaled and oral corticosteroids, some subjects with severe asthma had very few or no airway eosinophils (median 0 ; interquartile range, $0-2 / \mathrm{mm}^{2}$ ) (5). Pavord and colleagues identified a group of subjects with asthma with very few eosinophils and a poor response to corticosteroids (4). The same group later demonstrated in a cohort of patients with asthma who were not taking controller therapy that NEA is a distinct pathological entity with sputum eosinophils less than $2 \%$ and relatively few submucosal eosinophils (median, $4.4 / \mathrm{mm}^{2}$; interquartile range distance, $7.9 / \mathrm{mm}^{2}$ ) (8). Blood neutrophil levels have not been strongly correlated with airway neutrophil counts, however, and other reliable biomarkers of airway neutrophilia have not yet been established $(19,21,35)$.

\section{Clinical Characteristics of EA and NEA}

Although stratification by blood eosinophils is relatively easy, this does not create robust clinical phenotypes. Therefore, cluster analysis has been used to identify groups of patients with asthma who share specific clinical characteristics. For example, using unsupervised cluster analysis, which used clinical characteristics of age of asthma onset, lung function, bronchodilator reversibility, and demographics, the Severe Asthma Research Program (SARP) cohort identified five clinical clusters of adult asthma, in which four demonstrated eosinophilia of varying degrees $(36,37)$, and four clusters of pediatric asthma, all of which included eosinophilia (38). A recent investigation evaluating the ADEPT (Airways Disease Endotyping for Personalized Therapeutics) cohort identified four phenotypes, which were also present in the UBIOPRED (Unbiased Biomarkers for the Prediction of Respiratory Disease Outcome
Consortium) cohort (39). Three of the four asthma clusters were associated with eosinophilia. A representative comparison of the clinical clusters from the three mentioned cohorts as examples of the cluster analysis approach to defining clinical characteristics in asthma is presented in Table 1. Although cluster analysis can define groups of patients with asthma with specific shared clinical characteristics, it does not define specific endotypes, as it is likely that several endotypes drive the phenotypes present in each cluster.

To engage the concept of endotyping to shed light on mechanisms driving clinical phenotypes, histopathology, genetics, and treatment response of asthma, in addition to the variables used by cluster analysis, Lötvall and colleagues (40) proposed several endotypes driving multiple clinical phenotypes, emphasizing that a clinical phenotype may be driven by more than one endotype. Wenzel and colleagues (41) proposed grouping asthma into $\mathrm{Th} 2 / \mathrm{T} 2$ and non-Th2/T2, referring to the type of inflammation present, with many subendotypes leading to the commonly observed clinical phenotypes with and without eosinophils. The endotypes associated with clinical phenotypes characterized by eosinophilia included: early-onset allergic asthma with or without obesity, aspirin-sensitive asthma, late-onset EA, exacerbation-prone asthma, and exercise-induced asthma (Table 2, Figure 1). Clinical phenotypes of asthma not associated with eosinophils, and for which the pathobiologic pathways are not yet defined, include those patients with obesity-related late-onset asthma, asthma with fixed airflow obstruction and very little inflammation (paucigranulocytic), and asthma associated with neutrophilia (Table 2, Figure 1). Other noneosinophilic clinical phenotypes that are less well defined, but which may share similar endotypes, include smoking-related asthma, occupational asthma due to low molecular weight agents (42) or environmental pollution (43), and respiratory infections (44).

\section{Mechanisms of EA}

For clinicians and researchers, the implications of recognizing EA have two main facets. When assessing patients with 
Table 1. Comparison of Clinical Cluster Analyses in Three Large, Well-phenotyped Asthma Cohorts

\section{SARP Clusters}

UBIOPRED Clusters

\section{ADEPT Clusters}

1: Early onset, mild, atopic, eosinophilic

2: Early onset, moderate, atopic, eosinophilic

3: Late onset, nonatopic, eosinophilic, female, obese

4: Early onset, severe, atopic, reversible obstruction, eosinophilic

5: Late onset, long duration, severe, fixed airflow obstruction
US1: Mild asthma, good lung function, early onset, low inflammation

US2: Moderate, hyperresponsive, eosinophilic

US3: Mixed severity, mild reversible obstruction, noneosinophilic, neutrophilic

US4: Severe uncontrolled, severe reversible obstruction, mixed granulocytic
A1: Mild, normal lung function, early onset, low inflammation

A2: Moderate, atopic, mild reversible obstruction, hyperresponsive, eosinophilic

A3: Mixed severity, mild reversible obstruction, noneosinophilic, neutrophilic

A4: Severe uncontrolled, severe reversible obstruction, mixed granulocytic

Definition of abbreviations: ADEPT = Airways Disease Endotyping for Personalized Therapeutics; SARP = Severe Asthma Research Program; UBIOPRED = Unbiased Biomarkers for the Prediction of Respiratory Disease Outcome Consortium.

mild, moderate, or severe disease, eosinophilia can identify patients who may benefit more significantly from inhaled corticosteroids $(45,46)$. For patients with severe asthma, particularly among those not well controlled with high-dose inhaled steroids or requiring systemic steroids for disease control, the presence of eosinophilia can identify those patients appropriate for the biologic therapies that target eosinophils or related inflammatory pathways. With the observation that eosinophilia is identified across multiple clusters of asthma and disease severity, the focus is shifting toward defining the mechanisms underlying eosinophilia rather than simply identifying eosinophilia as present or absent. Indeed, multiple mechanisms have been identified and implicated in the initiation or potentiation of EA (47), particularly among the proposed asthma endotypes (Table 2). Among these emerging patterns are elevated IL-4 and IL-13 expression in earlyonset atopic asthma and predominant IL-5 expression in later-onset, or less-atopic asthma $(47,48)$ (Figure 2).

The eosinophil is a terminally differentiated granulocyte with a bilobed nucleus and characteristic acidophilic granules. The presence of large specific granules, also known as secondary granules, is a characteristic feature that distinguishes eosinophils from other granulocytes, such as neutrophils and basophils. Specific granules consist of a dense crystalline core and a matrix, surrounded by a membrane $(5,49)$. They contain a large number of mediators capable of inducing inflammation and/or tissue damage, including basic proteins, cytokines, chemokines, growth factors, and enzymes. The main mediators are proteins, including major basic protein (MBP) located in the core, and eosinophil cationic protein, eosinophil peroxidase, and eosinophilderived neurotoxin, which are located in the matrix (50). Primary granules are also present and contain Charcot-Leyden crystal protein, which exhibits lysophospholipase activity lipids. Lipid bodies, which are in the cytoplasm, are a key site of arachidonic acid esterification and eicosanoid production because of their high concentrations of relevant enzymes such as cyclooxygenases, 5-lipoxygenase, and leukotriene C4-synthase (51). Eosinophils also express a significant number of receptors, including cytokine receptors, pattern recognition receptors, Siglec 8, Fc receptors, lipid receptors, and major histocompatibility II receptors (49).

Eosinophil development in the bone marrow is stimulated by IL-3, IL-5, and granulocyte-macrophage colonystimulating factor, and tissue recruitment through IL-5-induced upregulation of selectins and integrins acting synergistically through tissue expression of the eotaxins (eotaxin-1 [CCL11], -2 [CCL24], and -3 [CCL26]). IL-5 is potently expressed by type 2 innate lymphoid cells (ILC2s) and Th2 cells; therefore, blood and tissue eosinophilia can serve as evidence of inflammation driven by both cell types.

Increased numbers of CD34 $4^{+} / \mathrm{IL}-5 \mathrm{Ra}^{+}$ eosinophil precursors have been identified in the bronchial biopsies of patients with asthma compared with control subjects without asthma (52). More recently, eosinophil progenitors isolated from the blood of patients with severe EA have been shown to have an exaggerated response to IL-5 in vitro, compared with eosinophil precursors from subjects with mild asthma, suggesting that in situ eosinophilopoiesis may have a clinically relevant role in severe EA (53). The differentiation of eosinophils is regulated by the transcription factors GATA-binding protein 1 (GATA-1), PU.1, and the CCAAT-enhancing binding protein family. GATA-1 and PU.1 synergistically promote transcription of MBP (54). GATA-1 is believed to have the most important role, as disruption of the GATA-1 gene in mice results in a strain completely devoid of eosinophils (55).

The proteins contained in eosinophil granules (i.e., MBP, eosinophil peroxidase, eosinophil cationic protein, and eosinophilderived neurotoxin) have direct toxic effects on host tissues and can promote inflammation $(56,57)$. Host factors, such as innate immune molecules like surfactant protein-A, may interact with eosinophils to promote or inhibit their antimicrobial function (58). Furthermore, eosinophils synthesize and release type 1 and type 2 inflammatory cytokines and chemokines, which can further modulate or stimulate the immune response (57). Therefore, far from being a passive biomarker, eosinophils play a significant role in disease pathogenesis and guide phenotypic characteristics in asthma.

\section{Mechanisms of Allergic EA}

The association between allergy and asthma is widely recognized. As a group, individuals with the "allergic asthma" endotype have earlier-onset disease that is triggered predominantly by exposure to aeroallergens and commonly seen with comorbid allergic rhinitis or other atopic disorders. 


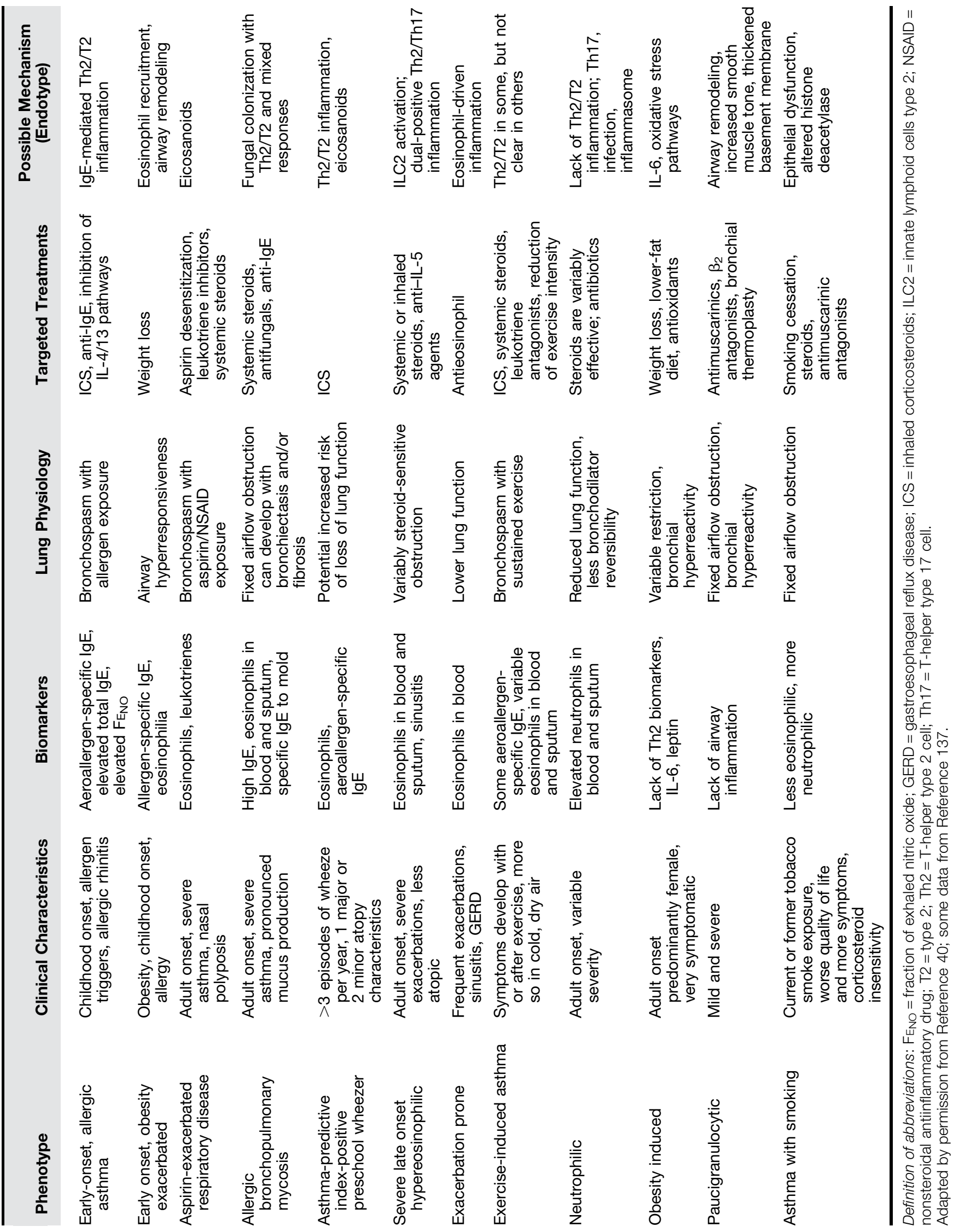




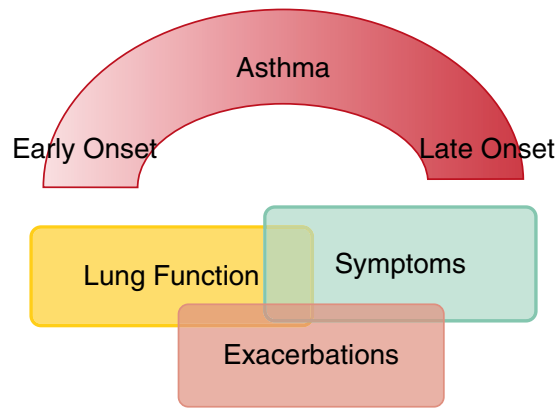

T2/Th2 Predominan

Non-T2/Th2
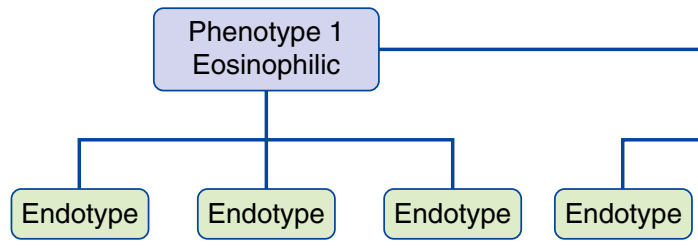

Phenotype 2 Noneosinophilic

Figure 1. Schematic representation of asthma and the spectrum of inflammation type and endotypes underlying clinical phenotypes. T2 = type 2; Th2 = T-helper type 2 cell. Adapted by permission from Reference 41

Characteristic of atopic disease, the type 2 inflammation seen in this asthma endotype is mediated by antigen-specific Th2 cells; secretion of IL-4, IL-5, and IL-13 from these and other cells; IgE-mediated mast cell and basophil degranulation; and eosinophilia (Figure 2). IL-5 recruits eosinophils to the site of antigen exposure, and the eotaxins establish a powerful chemotactic gradient inducing eosinophil influx into airways. Murine and ex vivo human experiments support that IL-13, also an eosinophil product $(49,57)$, contributes to the bronchial hyperreactivity characteristic of asthma $(47,59)$. Over time, these pathways may no longer require external stimulation and can become self-perpetuating (60). Airway remodeling may contribute to the persistent changes in lung function, which may be in part attributed to the presence of eosinophils through their expression of transforming growth factor- $\beta$ (61). Inhibition of IgE-mediated pathways through treatment with omalizumab can reduce the prominent viral-induced inflammation related to asthma exacerbations in atopic individuals (62).

Obesity is believed to exacerbate preexisting T2, EA through speculated mechanisms, including altered type 2 inflammation, suppressed CD4 effector cell function, and immune aging, as well as via remodeling and metabolic mechanisms (63-65). For example, a high-fat diet may increase bone marrow eosinophilia, with subsequent alteration in eosinophil trafficking $(63,66)$, and contribute to airway structural changes associated with increased collagen deposition (63). Lipid profiles consistent with metabolic syndrome negatively correlated with blood eosinophil counts in patients with atopic asthma, suggesting, type 2 inflammation in asthma may be modulated by lipids or related metabolic pathways not previously appreciated (67). In addition, inhibition of tumor necrosis factor (TNF)- $\alpha$, which is elevated in the airways of obese individuals, can lead to improvements in airway hyperresponsiveness and increased eosinophil apoptosis in obese mice and may function through mechanisms involving the antiinflammatory effects of surfactant protein-A $(68,69)$. Adipokines such as leptin, which is elevated in obesity, increased airway hyperresponsiveness and serum $\operatorname{IgE}$ in allergic mouse models $(63,70)$, whereas adiponectin reduces allergic inflammation and hyperresponsiveness, particularly at elevated serum levels (63). Additional mechanisms connecting obesity to increased type 2 and EA continue to be discovered, and additional work will be necessary to clarify these pathways $(71,73)$.

Allergic bronchopulmonary mycosis (ABPM) is a distinct disease entity related to allergic EA, characterized by a pronounced eosinophilic, neutrophilic, and lymphocytic response to mold exposure in the lung, most commonly to Aspergillus fumigatus (74). Although mold-specific IgE and markedly elevated total IgE levels are characteristic of this disease, patients with ABPM can have pronounced peripheral blood and sputum eosinophilia (75). The factors contributing to disease development are not well understood. However, A. fumigatus proteases have been shown to directly cause bronchial epithelial cell damage and stimulation of cytokines and chemokines (76). Aspergillus proteins are processed by dendritic cells, particularly those with HLA (human leukocyte antigen)DR2/DR5, which induce a potent type 2 inflammatory response (77). IL-4 receptor polymorphisms (78) and IL-10 promotor polymorphisms (79) increase sensitivity to type 2 inflammation and together may drive the development of ABPM. Furthermore, polymorphisms in toll-like receptors (80) and pulmonary surfactant protein-A (81) have been identified and likely participate in susceptibility to disease.

\section{Mechanisms of Nonallergic EA}

Allergy is not a prominent mechanism in some subphenotypes of EA. When asthma is distinguished by expression of IL-4, IL-5, and IL-13 from sputum cells, those with levels higher than healthy control subjects have higher peripheral blood eosinophil counts than those with low Th2 gene expression $(9,82)$. It is noted, however, that patients with asthma with lower sputum Th2 gene expression may still have significant peripheral blood eosinophilia (82). The presence of activated type 2 innate lymphoid cells (ILC2) in the airways of patients with asthma correlates with airway eosinophilia, asthma development, and severe asthma, and these cells seem to be an important local source of the IL-5 and IL-13 driving the nonatopic subgroup of EA (83). Indeed, a lack of peripheral blood ILC2s can also be used to distinguish NEA from EA (84).

The subphenotype of late-onset EA is characterized by severe asthma with persistently elevated sputum and peripheral blood eosinophilia that is relatively corticosteroid insensitive $(40,85,86)$. The nonatopic eosinophilic airway inflammation in this subgroup of asthma is likely induced by innate immune pathways 


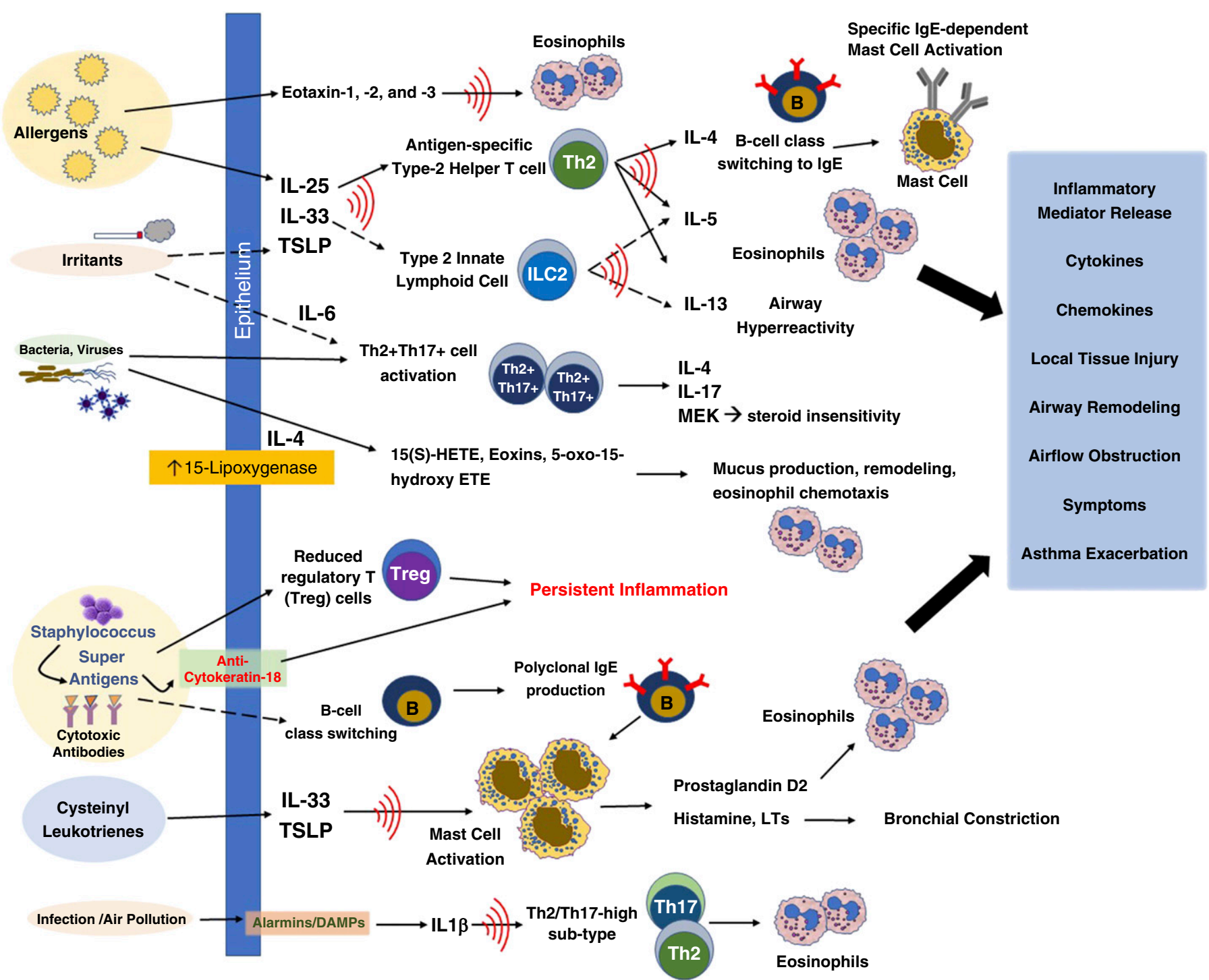

Figure 2. Mechanisms of eosinophilic asthma. DAMP = damage-associated molecular patterns; ETE = eicosatetraenoic acid; HETE = hydroxyeicosatetraenoic acid; LT = leukotriene; MEK = MAPKJERK kinase; Th = T-helper cell; TSLP = thymic stromal lymphopoeitin.

that include type 2 inflammatory pathways but in which IgE-mediated signals are not prominently contributing (Figure 2). Briefly stated, murine and human data suggest that irritants/pollutants and microbes induce airway epithelial injury, which in turn releases IL-25, IL-33, and TSLP (thymic stromal lymphopoeitin), stimulating ILC2s to release IL-5, promoting eosinophilia, and IL-13, thereby inducing airway hyperreactivity (47) (87). The lack of IL-4 production minimizes $\mathrm{B}$ cell class switching to $\operatorname{IgE}$, and therefore antigen-specific $\operatorname{IgE}$ is not prominent in these patients (47).

The presence of Th17-type inflammation may be contributing to the more severe, late-onset eosinophilic subphenotype. Irvin and colleagues reported the presence of helper $\mathrm{T}$ cells expressing both Th2 and Th17 cytokines (IL-4 and IL-17) in a subgroup of patients with asthma, in whom airway cells are predominantly eosinophilic and elevated blood eosinophil level is common (88). These patients with dual-positive asthma were clinically consistent with the lateonset eosinophilic phenotype, with more significant airway hyperresponsiveness, relative corticosteroid insensitivity, and no increased atopy when compared with the groups with only Th2 or neither Th2- nor Th17-predominant inflammation. This group then examined inflammatory markers in the BAL fluid and cells from patients with
Th2, Th17, and Th2/Th17 dual-positive asthma (89). The dual-positive group expressed more IL-6, IL-1 $\beta$, and IL-23 as well as other molecules related to Th17 pathways, and in vitro experiments suggested the induction of Th17 cells was subsequent to IL-1 $\beta$-mediated inflammation.

The exacerbation-prone phenotype of asthma describes individuals who have more than three exacerbations of asthma per year. Denlinger and colleagues (90) described a phenotype of exacerbationprone adults with asthma, which was not associated with asthma severity, duration, age of onset, race, socioeconomic background, or allergy. However, blood eosinophilia as well as elevated body 
mass index, sinusitis, and gastroesophageal reflux disease are prominent clinical features of this patient group. Although mechanisms underlying this phenotype are not well defined, the antiexacerbation benefit of eosinophil-targeted biologic drugs suggests the eosinophil contributes to the disease pathology $(15,16)$.

Although not extensively studied, mechanisms related to staphylococcal enterotoxins may also be important in the production of superantigens driving nonatopic eosinophilic disease (91). Superantigen exposure can drive class switching of local B cells, leading to polyclonal IgE production in the airways, resulting in non-antigen-specific mast cell activation. This leads to T-cell activation and suppression of regulatory $\mathrm{T}$ cells. Production of cytotoxic autoantibodies directed against epithelial proteins (i.e., cytokeratin-18) can also be detected. Superantigens can also contribute to loss of corticosteroid sensitivity in asthma leading to severe symptoms and may contribute to the steroid insensitivity seen in late-onset severe EA.

Aspirin-exacerbated respiratory disease (AERD) is a distinct clinical subphenotype of asthma that is also characterized by a specific endotype involving exposure to cyclooxygenase- 1 inhibitors such as aspirin or nonsteroidal antiinflammatory drugs. Patients have severe disease presenting as persistent asthma symptoms, refractory nasal polyposis, and chronic eosinophilic rhinosinusitis, which can be complicated by acute respiratory reactions on exposure to cyclooxygenase-1 inhibitors. Inflammation in these individuals is characterized by the overproduction of cysteinyl leukotrienes through the 5-lipoxygenase pathway, upregulation of cysteinyl leukotriene receptors, and increased production of prostaglandin D2 (92). Despite histologic and chemical evidence of ongoing mast cell activation, eosinophil recruitment, and eosinophil activation, individuals with AERD, although they have normal or elevated levels of serum IgE, often have no detectable antigen-specific IgE against common aeroallergens (93). Although these patients manifest notable EA, they are clearly distinct from those with classic type 2 allergic inflammation and may require disease-specific targeted interventions, including aspirin desensitization and blockade of leukotriene effect through 5-lipoxygenase inhibitors or leukotriene receptor antagonists.

Lipid mediators also contribute to asthma pathogenesis and inflammation in non-AERD eosinophilic and noneosinophilic phenotypes. The 15(s)hydroxyeicosatetraenoic acid metabolite of the 15-lipoxygenase pathway has been strongly linked to severe asthma with airway eosinophilia and associated subepithelial remodeling (94).

Furthermore, these 15-lipoxygenase pathways, which can be induced by infection or cell injury (95), have also been shown to affect intracellular airway epithelial cell signaling (96) and chemokine and cytokine production by lung macrophages (97) and to induce airway mucus production (98).

\section{Mechanisms of NEA}

Less is known about NEA. Similar to the case in EA, the literature supports multiple molecular pathways underlying each phenotype. Emerging subphenotypes of NEA include neutrophilic asthma, obesityinduced asthma, paucigranulocytic asthma, and asthma related to environmental exposures. Although atopy can be present in some of these patients, asthma with predominant neutrophilic inflammation or the paucigranulocytic subtype represent a relatively Th2/T2-low inflammatory milieu. Instead, pathways inducing neutrophilic inflammation and airway dysfunction are implicated.

\section{Mechanisms of Neutrophilic Asthma}

Corticosteroids are known to inhibit neutrophil apoptosis, which in turn may prolong or promote airway neutrophilia, potentially leading (or at least contributing) to the diagnosis of neutrophilic asthma (99). This calls into question whether the continued use of corticosteroids to treat severe neutrophilic asthma may promote or complicate diagnosis of the neutrophilic phenotype in patients using inhaled or systemic corticosteroids. Despite this, many potential molecular pathways may be implicated in the development of the neutrophilic asthma subphenotype independent of corticosteroid use (Figure 3). Clinically, patients with neutrophilic asthma develop asthma at an older age and demonstrate impaired lung function, less bronchodilator reversibility, and less atopy (Table 2) $(39,100)$.

Differential inflammation through both the acquired and innate immune pathways distinguishes neutrophilic asthma from EA. The innate immune pathway is activated during infection (viral, bacterial) or during irritant environmental exposure, such as endotoxin, ozone, and particulate matter exposures. Instead of triggering the aforementioned ILC2 or T2 pathways, these agents can activate toll-like receptor 4 and CD (cluster of differentiation)-14 on epithelial cells and macrophages leading to nuclear factor (NF)- $\mathrm{kB}$ activation, which in turn establishes a highly proinflammatory state $(101,102)$. This then leads to heightened production of IL-8, which recruits activated neutrophils into the airways (Figure 3).

Neutrophilic inflammation in asthma is related to markers of systemic inflammation and metabolic dysfunction, including elevation in biomarkers such as IL-6, C-reactive protein, and TNF- $\alpha(103,104)$. The extent to which IL-6 is pathogenic in neutrophilic asthma is not yet clear; however, in vitro studies of human airway smooth muscle suggest that trans-signaling of IL- 6 through the IL- 6 receptor may contribute to airway remodeling and smooth muscle cell proliferation in asthma (105).

It is very likely that other pathways and mechanisms contribute to airway neutrophilia either alone or in combination. One potential explanation for an increase in sputum neutrophil levels in neutrophilic asthma may be the result of impaired alveolar macrophage phagocytosis of apoptotic cells, termed "efferocytosis." In a study of patients with stable asthma undergoing sputum induction, macrophage efferocytosis was impaired in patients with neutrophilic asthma leading to persistent airway neutrophilia but was not impaired in those with EA (106). The mitogen-activated protein kinase family, including the p38 kinases, is activated in various inflammatory responses, including eosinophilia and neutrophilia. The p38 kinase is also induced by environmental triggers (e.g., endotoxin, oxidative stress, cigarette smoke, air pollution) relevant to asthma and in particular to NEA. Inhibition of $\mathrm{p} 38 /$ mitogen-activated protein kinase mitigates neutrophilic inflammation, which may thus play a role in neutrophilic asthma (107). 


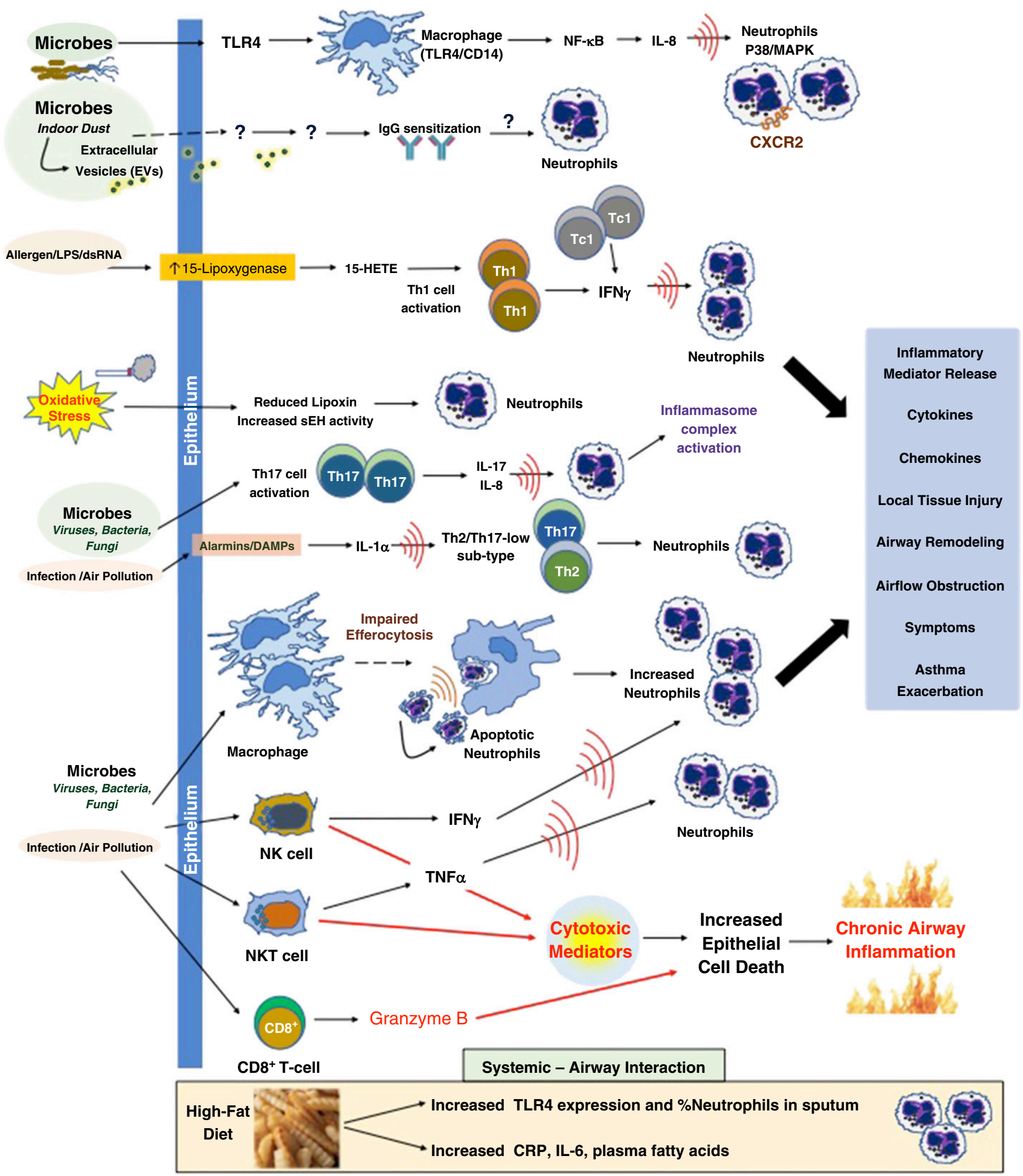

Figure 3. Mechanisms of noneosinophilic asthma. $\mathrm{CRP}=\mathrm{C}$-reactive protein; $\mathrm{CXCR2}=$ chemokine receptor 2; DAMP = damage-associated molecular patterns; dsRNA = double-stranded RNA; HETE = hydroxyeicosatetraenoic acid; MAPK = mitogen-activated protein kinase; NF-кB = nuclear factor $к B$; NK = natural killer; sEH = soluble epoxide hydrolase; Tc1 = cytotoxic T-cell subset 1; Th = T-helper cell; TLR4 = toll-like receptor 4; TNF $\alpha=$ tumor necrosis factor- $\alpha$. 
The lipoxins are endogenous arachidonate-derived proresolution mediators that decrease inflammation and are reduced in severe asthma. Lipoxins inhibit eosinophil trafficking and neutrophil chemotaxis, transcellular migration, and toxic degranulation, and may support natural killer cell function in severe asthma (108). Oxidative stress in asthmatic airways is associated with reduced lipoxin levels and with activity of the enzyme-soluble epoxide hydrolase. Inhibition of this enzyme increases lipoxin levels that mediate antiinflammatory pathways relevant to asthma (109). The antiinflammatory club cell secretory protein CC16 (approved symbol SCGB1A1) has been directly correlated with lung function (110) and may function as an antiinflammatory mediator through effects at the lipoxin A4 receptor, such as IL-8 and serum amyloid A inhibition (111). Treatments that enhance lipoxin levels or CC16 or inhibit soluble epoxide hydrolase may be beneficial in neutrophilic asthma, given the prominent cellular effects of lipoxins on lung neutrophils.

In neutrophilic asthma, there is evidence of upregulated nucleotide-binding domain, leucine-rich repeat-containing family protein-3 inflammasome activity (112). In a recent study using transcriptomeassociated clusters, the cluster that was characterized by IFN-, TNF-, and inflammasome-associated genes had the greatest sputum neutrophilia as compared with other clusters, which were, by contrast, associated with type 2 inflammation or metabolic/mitochondrial genes and sputum eosinophilia (113). This suggests a role for inflammasome mechanisms in neutrophilic asthma not previously appreciated.

NK and NKT-like cells are effector lymphocytes that are a major source of proinflammatory and cytotoxic mediators with relative corticosteroid insensitivity, which may contribute to the development of neutrophilic asthma. Evidence supporting this notion includes increased expression of cytotoxic markers in poorly controlled neutrophilic asthma. For example, in one cohort, subjects with poorly controlled neutrophilic asthma had higher expression of granzyme $\mathrm{B}$ by $\mathrm{CD}^{+} \mathrm{T}$ cells, greater IFN- $\gamma$ production by NK cells, and greater TNF- $\alpha$ production by NKT-like cells than healthy control subjects (114). Cytotoxic effects of granzyme B may lead to increased epithelial cell death and chronic inflammation, which contribute to persistent symptoms despite therapy with corticosteroids (115).

Because IL-17 can induce prominent neutrophilic inflammation, the IL-17 axis is gaining significant attention for its contribution to both neutrophilic (116) and mixed granulocytic airway inflammation. In asthma, Th17 inflammation is related to a severe phenotype, frequent exacerbations, steroid resistance, bronchial wall remodeling, mucus hypersecretion, and smooth muscle hypertrophy $(117,118)$. IL-17 may also contribute to severe asthma by inducing relative steroid unresponsiveness (119). Irvin and colleagues discovered that patients who lack significant Th2/Th17 inflammation have more significant airway neutrophilia than those with Th2 or Th2/Th17 dual-positive markers (88). The presence of type 2 cytokines may inhibit production of IL- 8 and thus abrogate the development of neutrophilia despite the presence of Th17-type

inflammation $(89,120)$. In the cohort by Liu and colleagues, many of those patients with neutrophilic asthma also had evidence for bacterial lung infection (89).

Chronic infection may be a key underlying stimulus for this Th17-type inflammatory pathway in asthma, given that Th17 cells produce IFN- $\gamma$ and IL-17 in addition to other proinflammatory cytokines, in response to bacterial and fungal infection (121, 122). Indeed, neutrophilic asthma could be a manifestation of individuals with asthma with underlying chronic subclinical infection or inhaled exposures (123). Biological contaminants in indoor air originating from microorganisms can lead to immune dysfunction and inflammation leading to or exacerbating lung disease. For example, extracellular vesicles originating from microorganisms in indoor dust can cause neutrophilic inflammation in asthma (124). In murine models, there is evidence suggesting that 15-lipoxygenase metabolites, such as 15-hydroxyeicosatetraenoic acid, are important mediators in the development of Th1 inflammation induced by ovalbumin and double-stranded RNA, as well as in the development of EA. This suggests that virusassociated neutrophilic asthma with high IFN- $\gamma$, an exacerbation-prone clinical phenotype, may be explained by a Th1 response via a 15-lipoxygenase mechanism (125).
A significant proportion of patients with asthma are current smokers, at rates similar to the general population (126). Multiple cohorts have described smokers with asthma as suffering from more severe disease and having fewer sputum eosinophils; ex-smokers and current smokers have predominant neutrophilic inflammation $(127,128)$. Steroid insensitivity in this phenotype may be due to alterations in histone deacetylase activity (129). Cigarette smoke is toxic to the respiratory epithelium (130) and in fact may induce type 2 inflammation from the subepithelial dendritic cells, even through in utero exposure $(131,132)$. Occupational asthma due to low-molecular-weight agents (42) and secondary to environmental pollution (43) may be induced by similar pathways.

Paucigranulocytic asthma represents up to $40 \%$ of NEA (133). Although paucigranulocytic asthma is associated with well-controlled or mild intermittent asthma in the SARP cohort (34), it can be severe and may not respond well to standard asthma medications, such as inhaled corticosteroids. The mechanisms underlying paucigranulocytic asthma are believed to be related to abnormalities or dysfunction of structural cells, including airway smooth muscle, nerves, and vascular tissue. Airway remodeling, such as airway smooth muscle hypertrophy and hyperplasia, subbasement membrane fibrosis, and mucus gland hypertrophy, may occur as a result of aberrant repair mechanisms (134). Airway bronchospasm can induce transforming growth factor- $\beta$ release and subbasement membrane fibrosis in the airway (135). Increased bronchomotor tone from muscarinic and adrenergic pathways can contribute to paucigranulocytic asthma symptoms and may be successfully treated with muscarinic and $\beta_{2}$ receptor antagonists $(136,137)$. Airway smooth muscle is abnormal in asthma, with even patients with mild asthma demonstrating hyperplasia (138). This abnormal airway smooth muscle can not only contract to cause airflow obstruction but also actively secrete chemokines and cytokines that promote and mediate inflammation $(139,140)$. Bronchial thermoplasty can reduce airway smooth muscle mass and collagen deposition and thereby reduce the risk of acute exacerbations (141). Therefore, bronchial thermoplasty may be very useful in this population of more severe paucigranulocytic asthma. However, its benefit in other asthma 
phenotypes and endotypes is not yet known and is currently under investigation.

\section{Mechanisms of Obesity-induced NEA}

Obesity and diet are increasingly recognized as important and interrelated variables in the development and severity of asthma. Obesity can complicate early-onset allergic asthma, as previously described. However, asthma can also be consequent to obesity, in a late-onset, female-predominant phenotype $(142,143)$. This obesity-induced asthma is associated with neutrophilic or paucigranulocytic airway inflammation with low eosinophil counts $(66,104)$. In these patients, peripheral lung tissue elastance and airway resistance are abnormally elevated, but the increased peripheral airway sensitivity to closure can be reversed with significant weight loss $(142,144)$. The mechanisms underlying these changes may relate to inflammation in the adipose tissue mediated by activated macrophages, causing increases in IL-6, TNF- $\alpha$, and leptin that are also reversible with weight loss (68). Interestingly, abnormal IL-6 inflammation can be detected in even nonobese patients with asthma (104), suggesting that metabolic pathways can be aberrant independent of body mass index. Patients with obesity-induced asthma may be more sensitive to environmental pollutants and irritants than those who are nonobese (63). For example, ozone exposure can decrease lung function, increase airway neutrophilia, and induce IL- 6 in obese women with asthma (71).

Dietary consumption of fat, antioxidants, and lycopene may impact this obese-asthma airway inflammation and lung function. Nonobese patients with asthma eating a high-fat meal developed a decrease in lung function and increase in sputum neutrophilia and toll-like receptor $4 \mathrm{mRNA}$ expression 4 hours post meal as compared with the low-fat group $(72,73)$. The genes involved in this high-fat meal mechanism in asthma include those important in immune system processes, including calcium ion binding/signal transduction, calcium binding signaling, T-cell differentiation, apoptosis, antimicrobial glycoproteins and mucosal protection, and noncanonical NF- $\kappa$ B activity, to name a few (70). In a high-fat diet mouse model of obese asthma, airway hyperreactivity was found to be independent of adaptive immunity, instead characterized by IL-17A released by ILC3 cells and macrophage-derived IL-1 $\beta$ (145). Consumption of a low antioxidant diet is associated with worse asthma symptoms, reduced lung function $\left(\mathrm{FEV}_{1}, \mathrm{FVC}\right)$, and increased percentage sputum neutrophils. Treatment with lycopene-rich supplements reduces sputum neutrophil elastase activity and may be useful in the treatment of NEA (76). Therefore, obesity is a complex modulator of inflammation that affects EA by perpetuating T2/Th2 inflammation and NEA as a distinct subphenotype driven by several mechanisms or endotypes.

\section{Implications for the Treatment of Asthma}
Although eosinophils contribute to inflammation in asthma and may be present because of more than one molecular mechanism, the depletion of eosinophils can improve asthma control and exacerbation risk in many patients with asthma. Specific biologics evaluated

Table 3. Representative Biologic Therapies in Use or under Investigation for Eosinophilic Asthma

\begin{tabular}{|c|c|c|c|c|}
\hline Target & Treatment & Studies & Patient Population & Outcomes \\
\hline \multirow[t]{2}{*}{ IL-5 } & $\begin{array}{l}\text { Anti-IL-5 lgG } \\
\text { mepolizumab* }\end{array}$ & $\begin{array}{l}\text { Bel et al., } 2014 \text { (15); Ortega } \\
\quad \text { et al., } 2014 \text { (16) }\end{array}$ & $\begin{array}{l}\text { Severe asthma, peripheral } \\
\text { blood eosinophilia } \geqslant 150 \\
\text { cells/ } \mu \text { l at screening or } \\
300 \text { cells/ } \mu \text { in the } \\
\text { preceding year }\end{array}$ & $\begin{array}{l}\text { Steroid sparing, reduced } \\
\text { exacerbations, improved } \\
\text { control }\end{array}$ \\
\hline & Reslizumab* & Castro et al., 2015 (146) & $\begin{array}{l}\text { Uncontrolled moderate to } \\
\text { severe asthma with } \\
\text { peripheral blood } \\
\text { eosinophilia } \geqslant 400 \text { cells } / \mu \text { l } \\
\text { and } \geqslant 1 \text { exacerbation in } \\
\text { the past year }\end{array}$ & Reduced exacerbations \\
\hline IL-5 receptor & Benralizumab & $\begin{array}{l}\text { Bleecker et al., } 2016 \text { (17); } \\
\text { FitzGerald et al., } 2016 \\
\text { (153) }\end{array}$ & $\begin{array}{l}\text { Severe asthma, peripheral } \\
\text { blood eosinophilia }> \\
300 / \mu l\end{array}$ & $\begin{array}{l}\text { Reduced exacerbations, } \\
\text { improved lung function } \\
\text { and symptom control }\end{array}$ \\
\hline $\lg E$ & Omalizumab* & Cochrane Review 2014 (154) & $\begin{array}{l}\text { FDA approved for treatment } \\
\text { of moderate to severe } \\
\text { allergic asthma, age } \geqslant 6 \mathrm{yr}\end{array}$ & $\begin{array}{l}\text { Improved asthma symptom } \\
\text { control, reduced } \\
\text { exacerbations, reduced } \\
\text { eosinophil counts }\end{array}$ \\
\hline IL-4 receptor, $\alpha$ subunit & Dupilumab & Wenzel et al., 2016 (149) & $\begin{array}{l}\text { Phase Ilb: Uncontrolled } \\
\text { moderate to severe } \\
\text { asthma }(n=769)\end{array}$ & $\begin{array}{l}\text { Improved lung function, } \\
\text { reduced exacerbations }\end{array}$ \\
\hline $\begin{array}{l}\text { Prostaglandin D2 } \\
\text { receptor } 2\end{array}$ & Fevipiprant & Gonem et al., 2016 (155) & $\begin{array}{l}\text { Phase II: Moderate to severe } \\
\text { asthma with sputum } \\
\text { eosinophils } \geqslant 2 \%\end{array}$ & $\begin{array}{l}\text { Reduced sputum } \\
\text { eosinophils, improved } \\
\text { quality of life and lung } \\
\text { function }\end{array}$ \\
\hline
\end{tabular}


as treatment for EA have helped to define what is "eosinophilic" and perpetuate the phenotypic distinction of EA versus NEA (15-17). Two IL-5 inhibitors, reslizumab (146) and mepolizumab (16), are available for clinical use in the United States for treatment of severe EA. One IL-5 receptor antagonist, benralizumab, has at the time of this review just received U.S. Food and Drug Administration approval for the treatment of severe EA (147). Furthermore, the presence of sputum or blood eosinophilia is a biomarker of response to systemic and inhaled corticosteroids $(4,8,148,149)$. EA may also benefit from non-IL-5-specific biologic therapies such as dupilumab, which inhibits both IL-4 and IL-13 signaling through blocking the IL-4 receptor alpha chain. However, benefits from dupilumab are not limited to those with eosinophilia (150). Biologic treatments in development for the treatment of severe EA also target type 2 inflammatory pathways and are listed in Table 3.

Table 4. Representative Therapeutics in Use or under Investigation for Noneosinophilic Asthma

\begin{tabular}{|c|c|c|c|c|}
\hline Target & Treatment & Studies & Patient Population & Outcomes \\
\hline $\begin{array}{l}\text { Muscarinic } \\
\text { receptors }\end{array}$ & $\begin{array}{l}\text { Tiotropium* (long-acting } \\
\text { muscarinic antagonist) }\end{array}$ & Iwamoto et al., 2008 (137) & Severe asthma $(n=17)$ & $\begin{array}{l}\text { Improvement in lung } \\
\text { function with increasing } \\
\text { sputum neutrophils }\end{array}$ \\
\hline \multirow[t]{2}{*}{ Bacteria } & $\begin{array}{l}\text { Clarithromycin (macrolide } \\
\text { antibiotic) }\end{array}$ & Simpson et al., 2008 (156) & $\begin{array}{l}\text { Severe refractory asthma } \\
\quad(n=45)\end{array}$ & $\begin{array}{l}\text { Improved QOL scores in } \\
\text { NEA }\end{array}$ \\
\hline & $\begin{array}{l}\text { Azithromycin (macrolide } \\
\text { antibiotic) }\end{array}$ & Brusselle et al., 2013 (157) & Severe asthma $(n=109)$ & $\begin{array}{l}\text { Fewer exacerbations and } \\
\text { lower respiratory } \\
\text { infections in NEA only }\end{array}$ \\
\hline $\begin{array}{l}\text { HMG-CoA } \\
\text { reductase }\end{array}$ & Atorvastatin & Braganza et al., 2011 (158) & $\begin{array}{l}\text { Smokers with asthma with NEA } \\
(n=71)\end{array}$ & $\begin{array}{l}\text { Improved QOL at } 4 \mathrm{wk} \text { but } \\
\text { not } 8 \mathrm{wk}\end{array}$ \\
\hline \multirow[t]{2}{*}{ PPAR $\gamma$} & Rosiglitazone (PPARy agonist) & Spears et al., 2009 (159) & $\begin{array}{l}\text { Smokers with mild to moderate } \\
\text { asthma }(n=46)\end{array}$ & $\begin{array}{l}\text { Improvement in lung } \\
\text { function at } 28 \mathrm{~d}\end{array}$ \\
\hline & Pioglitazone (PPAR $\gamma$ agonist) & Dixon et al., 2015 (160) & $\begin{array}{l}\text { Obese patients with asthma } \\
(n=23)\end{array}$ & No improvement; weight gain \\
\hline \multirow[t]{3}{*}{ PDE } & $\begin{array}{l}\text { Theophylline* (nonselective } \\
\text { PDE inhibitor) }\end{array}$ & Spears et al., 2009 (161) & $\begin{array}{l}\text { Smokers with asthma with NEA } \\
(n=68)\end{array}$ & $\begin{array}{l}\text { Improved symptoms and } \\
\text { peak flow at } 4 \text { wk }\end{array}$ \\
\hline & Roflumilast (PDE4 inhibitor) & Gauvreau et al., 2011 (162) & Mild allergic asthma $(n=25)$ & $\begin{array}{l}\text { Inhibits allergen-induced } \\
\text { increase in sputum } \\
\text { neutrophils and eosinophils }\end{array}$ \\
\hline & & Meltzer et al., 2015 (163) & $\begin{array}{l}\text { Pooled analysis of } 9 \text { randomized } \\
\text { studies on moderate to severe } \\
\text { asthma }(n=4,873)\end{array}$ & $\begin{array}{l}\text { Improved asthma symptom } \\
\text { control and lung function }\end{array}$ \\
\hline CXCR2 & $\begin{array}{l}\text { SCH527123 (CXCR2 } \\
\text { antagonist) }\end{array}$ & Nair et al., 2012 (164) & $\begin{array}{l}\text { Severe asthma with sputum } \\
\text { neutrophilia }>40 \%(n=34)\end{array}$ & Fewer mild exacerbations \\
\hline $\begin{array}{l}\text { IL-17 } \\
\quad \text { receptor }\end{array}$ & $\begin{array}{l}\text { Brodalumab (anti-IL-17RA } \\
\text { antibody) }\end{array}$ & Busse et al., 2013 (165) & $\begin{array}{l}\text { Moderate to severe asthma } \\
\quad(n=302)\end{array}$ & No improvement \\
\hline \multirow[t]{3}{*}{ TNF } & $\begin{array}{l}\text { Etanercept (soluble TNF- } \alpha \\
\text { receptor blocker) }\end{array}$ & Berry et al., 2006 (166) & Mild to severe asthma $(n=30)$ & $\begin{array}{l}\text { Improvement in QOL, lung } \\
\text { function, and bronchial } \\
\text { hyperreactivity }\end{array}$ \\
\hline & & Holgate et al., 2011 (167) & $\begin{array}{l}\text { Moderate to severe asthma } \\
\quad(n=132)\end{array}$ & No benefit \\
\hline & Golimumab (anti-TNF- $\alpha$ antibody) & Wenzel et al., 2009 (168) & Severe asthma $(n=309)$ & $\begin{array}{l}\text { Discontinued early; } \\
\text { unfavorable risk }\end{array}$ \\
\hline IL-1 & Anakinra (IL-1R antagonist) & www.clinicaltrials.gov & & - \\
\hline IL-6 & Sirukumab (anti-IL-6 antibody) & www.clinicaltrials.gov & & - \\
\hline $\begin{array}{l}\text { Protein } \\
\text { kinases }\end{array}$ & $\begin{array}{l}\text { Phosphoinositide } 3 \text { kinase } \\
\text { inhibitors } \\
\text { Tyrosine kinase inhibitors }\end{array}$ & Preclinical & - & - \\
\hline
\end{tabular}

Definition of abbreviations: CXCR2 = chemokine receptor 2; HMG-CoA = 3-hydroxy-3-methylglutaryl-coenzyme A; NEA = noneosinophilic asthma; $\mathrm{PDE}=$ phosphodiesterase; PPAR $\gamma=$ peroxisome proliferator-activated receptor- $\gamma ; \mathrm{QOL}=$ quality of life; TNF = tumor necrosis factor

*U.S. Food and Drug Administration approved at time of article submission for treatment of asthma. 


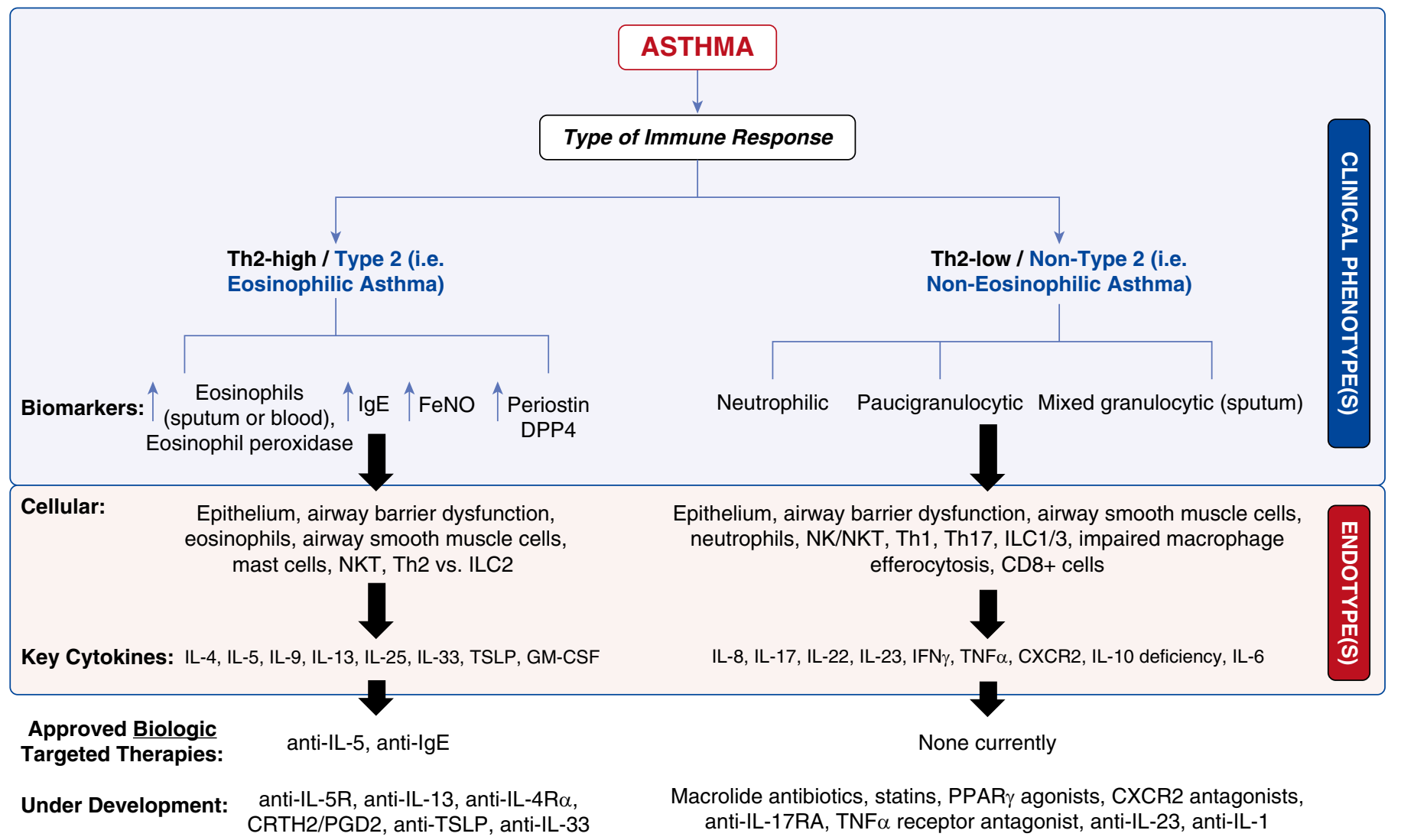

Figure 4. Clinical phenotypes, endotypes, and therapeutic options in eosinophilic and noneosinophilic asthma. CRTH2=chemoattractant receptor-homologous molecule expressed on T-helper type 2 cells; CXCR2 = chemokine receptor 2; DPP4 = dipeptidyl peptidase-4; FENO = fractional exhaled nitric oxide; GM-CSF = granulocyte-macrophage colony-stimulating factor; ILC = innate lymphoid cell; NK = natural killer; NKT = natural killer-T; PGD2 = prostaglandin D2; PPAR = peroxisome proliferator-activated receptor- $\gamma$; Th $=$ T-helper cell; TNF $\alpha=$ tumor necrosis factor- $\alpha$; TSLP = thymic stroll lymphopoeitin.

Given our limited understanding of what drives NEA, and the underlying mechanistic complexity of this phenotype, our therapies are likewise limited.

Nonpharmacologic prevention and treatment of NEA include smoking cessation, avoidance of environmental and occupational pollutants, dietary changes, and treatment of comorbid conditions that could lead to neutrophilic asthma, such as infection and obesity. Targeting the structural airway cells, through techniques such as bronchial thermoplasty, may prove to be useful in paucigranulocytic asthma or other phenotypes $(141,151)$.

Although the mainstay of asthma treatment is corticosteroids, clinical evidence indicates that NEA is generally poorly responsive to corticosteroid treatment in terms of symptoms and lung function $(4,8,11,152)$ and, furthermore, corticosteroid treatment could potentially worsen the disease. Off-label use of medications such as macrolide antibiotics, PDE (phosphodiesterase)-4 inhibitors, or statins in NEA appears to have limited or selective efficacy and/or they currently lack the clinical data to support their wider use in NEA. Additional focused studies are needed to evaluate several classes of these and novel small-molecule inhibitors and biologic agents that can be targeted to treat NEA, and some of these treatments are highlighted in Table 4.

\section{Conclusions}

Asthma is a complex syndrome that requires an integrated and holistic approach before major advances can lead to truly effective therapies for all patients (Figure 4). There is an urgent need to uncover new knowledge about the mechanisms and molecular phenotypes underlying the endotypes for both EA and NEA. We need to reconcile this phenotyping with the more descriptive cytokine-based or endotypic nomenclature.

Looking beyond our present focus on the mechanisms of EA and NEA, such cellular and molecular pathways must be contextualized and linked to the clinical scenario unique to each patient or cohort. The future of this discussion should also extend to an improved understanding of how each of these endotypes develops. We predict that different combinations of gene polymorphisms, epigenetic modifications, and early-life exposures will confer risk of development of each of the asthma endotypes.

Most important for effective patient care is the development of novel therapies that target these relevant molecular phenotypes in carefully designed individual or synergistic combination therapies that will lead to improved clinical outcomes. Such an approach should ultimately be guided by the identification and use of multiple biomarkers, which can reliably predict responses to therapy while also revealing emerging endotypes. The greatest need for novel therapies is in noneosinophilic phenotypes, such as neutrophilic or paucigranulocytic asthma, where no targeted biologic or other therapies are yet available and outcomes studies are still lacking.

Author disclosures are available with the text of this article at www.atsjournals.org. 


\section{References}

1. McGrath KW, Icitovic N, Boushey HA, Lazarus SC, Sutherland ER, Chinchilli VM, et al.; Asthma Clinical Research Network of the National Heart, Lung, and Blood Institute. A large subgroup of mild-tomoderate asthma is persistently noneosinophilic. Am J Respir Crit Care Med 2012;185:612-619.

2. Douwes J, Gibson P, Pekkanen J, Pearce N. Non-eosinophilic asthma: importance and possible mechanisms. Thorax 2002;57:643-648.

3. Brown HM. Treatment of chronic asthma with prednisolone; significance of eosinophils in the sputum. Lancet 1958;2:1245-1247.

4. Pavord ID, Brightling CE, Woltmann G, Wardlaw AJ. Non-eosinophilic corticosteroid unresponsive asthma. Lancet 1999;353:2213-2214.

5. Wenzel SE, Schwartz LB, Langmack EL, Halliday JL, Trudeau JB, Gibbs RL, et al. Evidence that severe asthma can be divided pathologically into two inflammatory subtypes with distinct physiologic and clinical characteristics. Am J Respir Crit Care Med 1999;160:1001-1008.

6. Szefler SJ, Wenzel S, Brown R, Erzurum SC, Fahy JV, Hamilton RG, et al. Asthma outcomes: biomarkers. J Allergy Clin Immunol 2012;129:S9-S23.

7. Arron JR, Choy DF, Scheerens H, Matthews JG. Noninvasive biomarkers that predict treatment benefit from biologic therapies in asthma. Ann Am Thorac Soc 2013;10:S206-S213.

8. Berry M, Morgan A, Shaw DE, Parker D, Green R, Brightling C, et al. Pathological features and inhaled corticosteroid response of eosinophilic and non-eosinophilic asthma. Thorax 2007;62:1043-1049.

9. Woodruff PG, Modrek B, Choy DF, Jia G, Abbas AR, Ellwanger A, et al. T-helper type 2-driven inflammation defines major subphenotypes of asthma. Am J Respir Crit Care Med 2009;180:388-395.

10. Jia G, Erickson RW, Choy DF, Mosesova S, Wu LC, Solberg OD, et al.; Bronchoscopic Exploratory Research Study of Biomarkers in Corticosteroid-refractory Asthma (BOBCAT) Study Group. Periostin is a systemic biomarker of eosinophilic airway inflammation in asthmatic patients. J Allergy Clin Immunol 2012;130:647-654.e10.

11. Cowan DC, Cowan JO, Palmay R, Williamson A, Taylor DR. Effects of steroid therapy on inflammatory cell subtypes in asthma. Thorax 2010;65:384-390.

12. Winkel P, Statland BE, Saunders AM, Osborn H, Kupperman H. Withinday physiologic variation of leukocyte types in healthy subjects as assayed by two automated leukocyte differential analyzers. Am J Clin Pathol 1981;75:693-700.

13. Dahl R. Diurnal variation in the number of circulating eosinophil leucocytes in normal controls and asthmatics. Acta Allergol 1977;32:301-303.

14. Christensen RD, Hill HR. Exercise-induced changes in the blood concentration of leukocyte populations in teenage athletes. $\mathrm{Am} \mathrm{J}$ Pediatr Hematol Oncol 1987:9:140-142.

15. Bel EH, Wenzel SE, Thompson PJ, Prazma CM, Keene ON, Yancey SW, et al.; SIRIUS Investigators. Oral glucocorticoid-sparing effect of mepolizumab in eosinophilic asthma. N Engl J Med 2014;371:1189-1197.

16. Ortega HG, Liu MC, Pavord ID, Brusselle GG, FitzGerald JM, Chetta A, et al.; MENSA Investigators. Mepolizumab treatment in patients with severe eosinophilic asthma. N Engl J Med 2014;371:1198-1207.

17. Bleecker ER, FitzGerald JM, Chanez P, Papi A, Weinstein SF, Barker $P$, et al.; SIROCCO study investigators. Efficacy and safety of benralizumab for patients with severe asthma uncontrolled with highdosage inhaled corticosteroids and long-acting $\beta 2$-agonists (SIROCCO): a randomised, multicentre, placebo-controlled phase 3 trial. Lancet 2016;388:2115-2127.

18. Ortega HG, Yancey SW, Mayer B, Gunsoy NB, Keene ON, Bleecker ER, et al. Severe eosinophilic asthma treated with mepolizumab stratified by baseline eosinophil thresholds: a secondary analysis of the DREAM and MENSA studies. Lancet Respir Med 2016;4:549-556.

19. Hastie AT, Moore WC, Li H, Rector BM, Ortega VE, Pascual RM, et al.; National Heart, Lung, and Blood Institute's Severe Asthma Research Program. Biomarker surrogates do not accurately predict sputum eosinophil and neutrophil percentages in asthmatic subjects. J Allergy Clin Immunol 2013;132:72-80.

20. Wagener AH, de Nijs SB, Lutter R, Sousa AR, Weersink EJ, Bel EH, et al. External validation of blood eosinophils, $\mathrm{FE}(\mathrm{NO})$ and serum periostin as surrogates for sputum eosinophils in asthma. Thorax 2015;70:115-120.

21. Zhang XY, Simpson JL, Powell H, Yang IA, Upham JW, Reynolds PN, et al. Full blood count parameters for the detection of asthma inflammatory phenotypes. Clin Exp Allergy 2014;44:1137-1145.
22. Westerhof GA, Korevaar DA, Amelink M, de Nijs SB, de Groot JC Wang $\mathrm{J}$, et al. Biomarkers to identify sputum eosinophilia in different adult asthma phenotypes. Eur Respir J 2015;46:688-696.

23. Cheng D, Xue Z, Yi L, Shi H, Zhang K, Huo X, et al. Epithelial interleukin-25 is a key mediator in Th2-high, corticosteroid-responsive asthma. Am $J$ Respir Crit Care Med 2014;190:639-648.

24. Simpson JL, Yang IA, Upham JW, Reynolds PN, Hodge S, James AL, et al. Periostin levels and eosinophilic inflammation in poorlycontrolled asthma. BMC Pulm Med 2016;16:67.

25. Shiobara T, Chibana K, Watanabe T, Arai R, Horigane Y, Nakamura Y, et al. Dipeptidyl peptidase-4 is highly expressed in bronchial epithelial cells of untreated asthma and it increases cell proliferation along with fibronectin production in airway constitutive cells. Respir Res 2016;17:28.

26. Brightling CE, Chanez P, Leigh R, O'Byrne PM, Korn S, She D, et al. Efficacy and safety of tralokinumab in patients with severe uncontrolled asthma: a randomised, double-blind, placebocontrolled, phase 2b trial. Lancet Respir Med 2015;3:692-701.

27. Berry MA, Shaw DE, Green RH, Brightling CE, Wardlaw AJ, Pavord ID. The use of exhaled nitric oxide concentration to identify eosinophilic airway inflammation: an observational study in adults with asthma. Clin Exp Allergy 2005;35:1175-1179.

28. Nair P, Ochkur SI, Protheroe C, Radford K, Efthimiadis A, Lee NA, et al. Eosinophil peroxidase in sputum represents a unique biomarker of airway eosinophilia. Allergy 2013;68:1177-1184.

29. Rank MA, Ochkur SI, Lewis JC, Teaford HG III, Wesselius LJ, Helmers RA et al. Nasal and pharyngeal eosinophil peroxidase levels in adults with poorly controlled asthma correlate with sputum eosinophilia. Allergy 2016;71:567-570.

30. Fens N, van der Sluijs KF, van de Pol MA, Dijkhuis A, Smids BS, van der Zee JS, et al.; RESOLVE Research Team. Electronic nose identifies bronchoalveolar lavage fluid eosinophils in asthma. Am J Respir Crit Care Med 2015;191:1086-1088.

31. Fowler SJ, Tavernier G, Niven R. High blood eosinophil counts predict sputum eosinophilia in patients with severe asthma. J Allergy Clin Immunol 2015;135:822-824.e2.

32. Westerhof GA, Vollema EM, Weersink EJ, Reinartz SM, de Nijs SB, Bel EH. Predictors for the development of progressive severity in new-onset adult asthma. J Allergy Clin Immunol 2014;134:1051-1056.e2.

33. Thomson NC. Novel approaches to the management of noneosinophilic asthma. Ther Adv Respir Dis 2016;10:211-234.

34. Moore WC, Hastie AT, Li X, Li H, Busse WW, Jarjour NN, et al. Sputum neutrophil counts are associated with more severe asthma phenotypes using cluster analysis. J Allergy Clin Immunol 2014;133:1557-1563.e5.

35. Schleich FN, Manise M, Sele J, Henket M, Seidel L, Louis R. Distribution of sputum cellular phenotype in a large asthma cohort: predicting factors for eosinophilic vs neutrophilic inflammation. BMC Pulm Med 2013;13:11.

36. Moore WC, Bleecker ER, Curran-Everett D, Erzurum SC, Ameredes BT, Bacharier L, et al.; National Heart, Lung, Blood Institute's Severe Asthma Research Program. Characterization of the severe asthma phenotype by the National Heart, Lung, and Blood Institute's Severe Asthma Research Program. J Allergy Clin Immunol 2007;119:405-413.

37. Moore WC, Meyers DA, Wenzel SE, Teague WG, Li H, Li X, et al.; National Heart, Lung, and Blood Institute's Severe Asthma Research Program. Identification of asthma phenotypes using cluster analysis in the Severe Asthma Research Program. Am J Respir Crit Care Med 2010; 181:315-323.

38. Fitzpatrick AM, Teague WG, Meyers DA, Peters SP, Li X, Li H, et al. Heterogeneity of severe asthma in childhood: confirmation by cluster analysis of children in the National Institutes of Health/National Heart, Lung, and Blood Institute Severe Asthma Research Program. $J$ Allergy Clin Immunol 2011;127:382-389.e1-13.

39. Loza MJ, Adcock I, Auffray C, Chung KF, Djukanovic R, Sterk PJ, et al.; ADEPT and U-BIOPRED Investigators. Longitudinally stable, clinically defined clusters of patients with asthma independently identified in the ADEPT and U-BIOPRED asthma studies. Ann Am Thorac Soc 2016;13:S102-S103.

40. Lötvall J, Akdis CA, Bacharier LB, Bjermer L, Casale TB, Custovic A, et al. Asthma endotypes: a new approach to classification of disease entities within the asthma syndrome. J Allergy Clin Immunol 2011;127:355-360.

41. Wenzel SE. Asthma phenotypes: the evolution from clinical to molecular approaches. Nat Med 2012;18:716-725. 
42. Anees W, Huggins V, Pavord ID, Robertson AS, Burge PS. Occupational asthma due to low molecular weight agents: eosinophilic and non-eosinophilic variants. Thorax 2002;57:231-236.

43. Wallace J, D'silva L, Brannan J, Hargreave FE, Kanaroglou P, Nair P. Association between proximity to major roads and sputum cell counts. Can Respir J 2011;18:13-18.

44. Metz G, Kraft M. Effects of atypical infections with Mycoplasma and Chlamydia on asthma. Immunol Allergy Clin North Am 2010;30: 575-585, vii-viii.

45. Hargreave FE. Induced sputum and response to glucocorticoids. J Allergy Clin Immunol 1998;102:S102-S105.

46. Szefler SJ, Martin RJ, King TS, Boushey HA, Cherniack RM, Chinchilli VM, et al.; Asthma Clinical Research Network of the National Heart Lung, and Blood Institute. Significant variability in response to inhaled corticosteroids for persistent asthma. J Allergy Clin Immunol 2002;109:410-418.

47. Lambrecht BN, Hammad H. The immunology of asthma. Nat Immunol 2015;16:45-56.

48. Brusselle GG, Maes T, Bracke KR. Eosinophils in the spotlight: eosinophilic airway inflammation in nonallergic asthma. Nat Med 2013;19:977-979.

49. McBrien CN, Menzies-Gow A. The biology of eosinophils and their role in asthma. Front Med (Lausanne) 2017;4:93.

50. Giembycz MA, Lindsay MA. Pharmacology of the eosinophil. Pharmacol Rev 1999;51:213-340.

51. Shamri R, Xenakis JJ, Spencer LA. Eosinophils in innate immunity: an evolving story. Cell Tissue Res 2011;343:57-83.

52. Robinson DS, Damia R, Zeibecoglou K, Molet S, North J, Yamada T, et al. CD34(+)/interleukin-5Ralpha messenger RNA+ cells in the bronchial mucosa in asthma: potential airway eosinophil progenitors. Am J Respir Cell Mol Biol 1999;20:9-13.

53. Sehmi R, Smith SG, Kjarsgaard M, Radford K, Boulet LP, Lemiere C, et al. Role of local eosinophilopoietic processes in the development of airway eosinophilia in prednisone-dependent severe asthma. Clin Exp Allergy 2016;46:793-802.

54. Du J, Stankiewicz MJ, Liu Y, Xi Q, Schmitz JE, Lekstrom-Himes JA, et al. Novel combinatorial interactions of GATA-1, PU.1, and C/EBPepsilon isoforms regulate transcription of the gene encoding eosinophil granule major basic protein. J Biol Chem 2002;277:43481-43494.

55. Yu C, Cantor AB, Yang H, Browne C, Wells RA, Fujiwara $Y$, et al. Targeted deletion of a high-affinity GATA-binding site in the GATA-1 promoter leads to selective loss of the eosinophil lineage in vivo. $J$ Exp Med 2002;195:1387-1395.

56. Fulkerson PC, Rothenberg ME. Targeting eosinophils in allergy, inflammation and beyond. Nat Rev Drug Discov 2013;12:117-129.

57. Carr TF, Berdnikovs S, Simon HU, Bochner BS, Rosenwasser LJ. Eosinophilic bioactivities in severe asthma. World Allergy Organ $J$ 2016;9:21.

58. Ledford JG, Mukherjee S, Kislan MM, Nugent JL, Hollingsworth JW, Wright JR. Surfactant protein-A suppresses eosinophil-mediated killing of Mycoplasma pneumoniae in allergic lungs. Plos One 2012;7:e32436.

59. Kaur D, Gomez E, Doe C, Berair R, Woodman L, Saunders R, et al. IL-33 drives airway hyper-responsiveness through IL-13-mediated mast cell: airway smooth muscle crosstalk. Allergy 2015;70:556-567.

60. Borish L. The immunology of asthma: asthma phenotypes and their implications for personalized treatment. Ann Allergy Asthma Immunol 2016:117:108-114.

61. Minshall EM, Leung DY, Martin RJ, Song YL, Cameron L, Emst P, et al. Eosinophil-associated TGF-beta1 mRNA expression and airways fibrosis in bronchial asthma. Am J Respir Cell Mol Biol 1997;17:326-333.

62. Teach SJ, Gill MA, Togias A, Sorkness CA, Arbes SJ Jr, Calatroni A, et al. Preseasonal treatment with either omalizumab or an inhaled corticosteroid boost to prevent fall asthma exacerbations. J Allergy Clin Immunol 2015;136:1476-1485.

63. Dixon AE, Poynter ME. Mechanisms of asthma in obesity: pleiotropic aspects of obesity produce distinct asthma phenotypes. Am J Respir Cell Mol Biol 2016;54:601-608.

64. Desai D, Newby C, Symon FA, Haldar P, Shah S, Gupta S, et al. Elevated sputum interleukin- 5 and submucosal eosinophilia in obese individuals with severe asthma. Am J Respir Crit Care Med 2013;188:657-663.

65. Haldar P, Pavord ID, Shaw DE, Berry MA, Thomas M, Brightling CE, et al. Cluster analysis and clinical asthma phenotypes. Am J Respir Crit Care Med 2008;178:218-224.
66. Sideleva O, Suratt BT, Black KE, Tharp WG, Pratley RE, Forgione P, et al. Obesity and asthma: an inflammatory disease of adipose tissue not the airway. Am J Respir Crit Care Med 2012;186:598-605.

67. Barochia AV, Gordon EM, Kaler M, Cuento RA, Theard P, Figueroa DM, et al. High density lipoproteins and type 2 inflammatory biomarkers are negatively correlated in atopic asthmatics. $J$ Lipid Res 2017;58:1713-1721.

68. Sideleva O, Black K, Dixon AE. Effects of obesity and weight loss on airway physiology and inflammation in asthma. Pulm Pharmacol Ther 2013;26:455-458.

69. Lugogo N, Francisco D, Addison KJ, Manne A, Pederson W, Ingram JL, et al. Obese asthmatic patients have decreased surfactant protein $A$ levels: mechanisms and implications. J Allergy Clin Immunol [online ahead of print] 15 Jun 2017; DOI:10.1016/j.jaci.2017.05.028

70. Li Q, Baines KJ, Gibson PG, Wood LG. Changes in expression of genes regulating airway inflammation following a high-fat mixed meal in asthmatics. Nutrients 2016;8:30.

71. Bennett WD, Ivins S, Alexis NE, Wu J, Bromberg PA, Brar SS, et al. Effect of obesity on acute ozone-induced changes in airway function, reactivity, and inflammation in adult females. Plos One 2016;11:e0160030.

72. Wood LG, Garg ML, Powell H, Gibson PG. Lycopene-rich treatments modify noneosinophilic airway inflammation in asthma: proof of concept. Free Radic Res 2008;42:94-102.

73. Wood LG, Garg ML, Gibson PG. A high-fat challenge increases airway inflammation and impairs bronchodilator recovery in asthma. $J$ Allergy Clin Immunol 2011;127:1133-1140.

74. Greenberger PA, Bush RK, Demain JG, Luong A, Slavin RG, Knutsen AP. Allergic bronchopulmonary aspergillosis. J Allergy Clin Immunol Pract 2014;2:703-708.

75. Agarwal R, Sehgal IS, Dhooria S, Aggarwal AN. Developments in the diagnosis and treatment of allergic bronchopulmonary aspergillosis. Expert Rev Respir Med 2016;10:1317-1334.

76. Kauffman HF, Tomee JF, van de Riet MA, Timmerman AJ, Borger P. Protease-dependent activation of epithelial cells by fungal allergens leads to morphologic changes and cytokine production. J Allergy Clin Immunol 2000;105:1185-1193.

77. Chauhan B, Santiago L, Hutcheson PS, Schwartz HJ, Spitznagel E, Castro $\mathrm{M}$, et al. Evidence for the involvement of two different MHC class II regions in susceptibility or protection in allergic bronchopulmonary aspergillosis. J Allergy Clin Immunol 2000;106:723-729.

78. Knutsen AP, Kariuki B, Consolino JD, Warrier MR. IL-4 alpha chain receptor (IL-4Ralpha) polymorphisms in allergic bronchopulmonary aspergillosis. Clin Mol Allergy 2006;4:3.

79. Brouard J, Knauer N, Boelle PY, Corvol H, Henrion-Caude A, Flamant C, et al. Influence of interleukin-10 on Aspergillus fumigatus infection in patients with cystic fibrosis. J Infect Dis 2005;191:1988-1991.

80. Carvalho A, Pasqualotto AC, Pitzurra L, Romani L, Denning DW, Rodrigues F. Polymorphisms in toll-like receptor genes and susceptibility to pulmonary aspergillosis. J Infect Dis 2008;197:618-621.

81. Saxena S, Madan T, Shah A, Muralidhar K, Sarma PU. Association of polymorphisms in the collagen region of SP-A2 with increased levels of total IgE antibodies and eosinophilia in patients with allergic bronchopulmonary aspergillosis. J Allergy Clin Immunol 2003;111: 1001-1007.

82. Peters MC, Mekonnen ZK, Yuan S, Bhakta NR, Woodruff PG, Fahy JV. Measures of gene expression in sputum cells can identify TH2-high and TH2-low subtypes of asthma. J Allergy Clin Immunol 2014;133: 388-394.

83. Smith SG, Chen R, Kjarsgaard M, Huang C, Oliveria JP, O'Byrne PM, et al. Increased numbers of activated group 2 innate lymphoid cells in the airways of patients with severe asthma and persistent airway eosinophilia. J Allergy Clin Immunol 2016;137:75-86.e8.

84. Liu T, Wu J, Zhao J, Wang J, Zhang Y, Liu L,et al. Type 2 innate lymphoid cells: a novel biomarker of eosinophilic airway inflammation in patients with mild to moderate asthma. Respir Med 2015;109:1391-1396.

85. Miranda C, Busacker A, Balzar S, Trudeau J, Wenzel SE. Distinguishing severe asthma phenotypes: role of age at onset and eosinophilic inflammation. J Allergy Clin Immunol 2004;113:101-108.

86. Phipatanakul W, Mauger DT, Sorkness RL, Gaffin JM, Holguin F, Woodruff PG, et al.; Severe Asthma Research Program. Effects of age and disease severity on systemic corticosteroid responses in asthma. Am J Respir Crit Care Med 2017;195:1439-1448. 
87. Fallon PG, Ballantyne SJ, Mangan NE, Barlow JL, Dasvarma A, Hewett DR, et al. Identification of an interleukin (IL)-25-dependent cell population that provides IL-4, IL-5, and IL-13 at the onset of helminth expulsion. $J$ Exp Med 2006;203:1105-1116.

88. Irvin C, Zafar I, Good J, Rollins D, Christianson C, Gorska MM, et al. Increased frequency of dual-positive TH2/TH17 cells in bronchoalveolar lavage fluid characterizes a population of patients with severe asthma. $J$ Allergy Clin Immunol 2014;134:1175-1186.e7.

89. Liu W, Liu S, Verma M, Zafar I, Good JT, Rollins D, et al. Mechanism of TH2/TH17-predominant and neutrophilic TH2/TH17-low subtypes of asthma. J Allergy Clin Immunol 2017;139:1548-1558.e4.

90. Denlinger LC, Phillips BR, Ramratnam S, Ross K, Bhakta NR, Cardet JC, et al.; National Heart, Lung, and Blood Institute's Severe Asthma Research Program-3 Investigators. Inflammatory and comorbid features of patients with severe asthma and frequent exacerbations. Am J Respir Crit Care Med 2017;195:302-313.

91. Barnes PJ. Intrinsic asthma: not so different from allergic asthma but driven by superantigens? Clin Exp Allergy 2009;39:1145-1151.

92. Laidlaw TM, Boyce JA. Aspirin-exacerbated respiratory disease-new prime suspects. N Engl J Med 2016;374:484-488.

93. Laidlaw TM, Boyce JA. Pathogenesis of aspirin-exacerbated respiratory disease and reactions. Immunol Allergy Clin North Am 2013;33:195-210.

94. Chu HW, Balzar S, Westcott JY, Trudeau JB, Sun Y, Conrad DJ, et al. Expression and activation of 15-lipoxygenase pathway in severe asthma: relationship to eosinophilic phenotype and collagen deposition. Clin Exp Allergy 2002;32:1558-1565.

95. Brunnström $\AA$, Tryselius $Y$, Feltenmark $S$, Andersson $E$, Leksell $H$, James A, et al. On the biosynthesis of 15-HETE and eoxin C4 by human airway epithelial cells. Prostaglandins Other Lipid Mediat 2015;121:83-90.

96. Zhao J, O'Donnell VB, Balzar S, St Croix CM, Trudeau JB, Wenzel SE. 15-Lipoxygenase 1 interacts with phosphatidylethanolamine-binding protein to regulate MAPK signaling in human airway epithelial cells. Proc Natl Acad Sci USA 2011;108:14246-14251.

97. Abrial C, Grassin-Delyle S, Salvator H, Brollo M, Naline E, Devillier P. 15-Lipoxygenases regulate the production of chemokines in human lung macrophages. Br J Pharmacol 2015;172:4319-4330.

98. Zhao J, Maskrey B, Balzar S, Chibana K, Mustovich A, Hu H, et al. Interleukin-13-induced MUC5AC is regulated by 15-lipoxygenase 1 pathway in human bronchial epithelial cells. Am J Respir Crit Care Med 2009;179:782-790.

99. Wang M, Gao P, Wu X, Chen Y, Feng Y, Yang Q, et al. Impaired antiinflammatory action of glucocorticoid in neutrophil from patients with steroid-resistant asthma. Respir Res 2016;17:153.

100. Hastie AT, Moore WC, Meyers DA, Vestal PL, Li H, Peters SP, et al.; National Heart, Lung, and Blood Institute Severe Asthma Research Program. Analyses of asthma severity phenotypes and inflammatory proteins in subjects stratified by sputum granulocytes. J Allergy Clin Immunol 2010;125:1028-1036.e13.

101. Green BJ, Wiriyachaiporn S, Grainge C, Rogers GB, Kehagia V, Lau L, et al. Potentially pathogenic airway bacteria and neutrophilic inflammation in treatment resistant severe asthma. Plos One 2014;9:e100645.

102. Wood LG, Baines KJ, Fu J, Scott HA, Gibson PG. The neutrophilic inflammatory phenotype is associated with systemic inflammation in asthma. Chest 2012;142:86-93.

103. Fu JJ, Baines KJ, Wood LG, Gibson PG. Systemic inflammation is associated with differential gene expression and airway neutrophilia in asthma. OMICS 2013;17:187-199.

104. Peters MC, McGrath KW, Hawkins GA, Hastie AT, Levy BD, Israel E, et al.; National Heart, Lung, and Blood Institute Severe Asthma Research Program. Plasma interleukin-6 concentrations, metabolic dysfunction, and asthma severity: a cross-sectional analysis of two cohorts. Lancet Respir Med 2016;4:574-584.

105. Robinson MB, Deshpande DA, Chou J, Cui W, Smith S, Langefeld C, et al. IL-6 trans-signaling increases expression of airways disease genes in airway smooth muscle. Am J Physiol Lung Cell Mol Physiol 2015;309:L129-L138.

106. Simpson JL, Gibson PG, Yang IA, Upham J, James A, Reynolds PN, et al.; AMAZES Study Research Group. Impaired macrophage phagocytosis in non-eosinophilic asthma. Clin Exp Allergy 2013;43:29-35.

107. Chung KF. p38 mitogen-activated protein kinase pathways in asthma and COPD. Chest 2011;139:1470-1479.
108. Duvall MG, Barnig C, Cernadas M, Ricklefs I, Krishnamoorthy N, Grossman NL, et al.; National Heart Lung, and Blood Institute's Severe Asthma Research Program-3 Investigators. Natural killer cell-mediated inflammation resolution is disabled in severe asthma. Sci Immunol 2017;2:pii:eaam5446.

109. Ono E, Dutile S, Kazani S, Wechsler ME, Yang J, Hammock BD, et al.; National Heart, Lung, and Blood Institute's Asthma Clinical Research Network. Lipoxin generation is related to soluble epoxide hydrolase activity in severe asthma. Am J Respir Crit Care Med 2014;190:886-897.

110. Guerra S, Halonen M, Vasquez MM, Spangenberg A, Stern DA, Morgan WJ, et al. Relation between circulating CC16 concentrations, lung function, and development of chronic obstructive pulmonary disease across the lifespan: a prospective study. Lancet Respir Med 2015;3:613-620.

111. Antico G, Aloman M, Lakota K, Miele L, Fiore S, Sodin-Semrl S. Uteroglobin, a possible ligand of the lipoxin receptor inhibits serum amyloid A-driven inflammation. Mediators Inflamm 2014;2014:876395.

112. Kim RY, Pinkerton JW, Essilfie AT, Robertson AAB, Baines KJ, Brown $A C$, et al. Role for NLRP3 inflammasome-mediated, IL-1 $\beta$ dependent responses in severe, steroid-resistant asthma. Am J Respir Crit Care Med 2017;196:283-297.

113. Kuo CS, Pavlidis S, Loza M, Baribaud F, Rowe A, Pandis I, et al.; U-BIOPRED Study group. T-helper cell type 2 (Th2) and non-Th2 molecular phenotypes of asthma using sputum transcriptomics in U-BIOPRED. Eur Respir J 2017;49:pii:1602135.

114. Hodge S, Hodge G, Simpson JL, Yang IA, Upham J, James A, et al.; AMAZES Study Research Group. Blood cytotoxic/inflammatory mediators in non-eosinophilic asthma. Clin Exp Allergy 2016;46:60-70.

115. Simpson JL, Gibson PG, Yang IA, Upham J, James A, Reynolds PN, et al.; AMAZES Study Research Group. Altered sputum granzyme B and granzyme $B /$ proteinase inhibitor-9 in patients with noneosinophilic asthma. Respirology 2014;19:280-287.

116. Chesné J, Braza F, Mahay G, Brouard S, Aronica M, Magnan A. IL-17 in severe asthma: where do we stand? Am J Respir Crit Care Med 2014;190:1094-1101.

117. Cosmi L, Liotta F, Annunziato F. Th17 regulating lower airway disease. Curr Opin Allergy Clin Immunol 2016;16:1-6.

118. Ricciardolo FLM, Sorbello V, Folino A, Gallo F, Massaglia GM, Favatà G, et al. Identification of IL-17F/frequent exacerbator endotype in asthma. $J$ Allergy Clin Immunol 2017;140:395-406.

119. McKinley L, Alcorn JF, Peterson A, Dupont RB, Kapadia S, Logar A, et al. TH17 cells mediate steroid-resistant airway inflammation and airway hyperresponsiveness in mice. J Immunol 2008;181:4089-4097.

120. Choy DF, Hart KM, Borthwick LA, Shikotra A, Nagarkar DR, Siddiqui S, et al. TH2 and TH17 inflammatory pathways are reciprocally regulated in asthma. Sci Transl Med 2015;7:301ra129.

121. Acosta-Rodriguez EV, Rivino L, Geginat J, Jarrossay D, Gattorno M, Lanzavecchia A, et al.. Surface phenotype and antigenic specificity of human interleukin 17-producing T helper memory cells. Nat Immunol 2007;8:639-646.

122. Bettelli E, Korn T, Oukka M, Kuchroo VK. Induction and effector functions of $\mathrm{T}(\mathrm{H}) 17$ cells. Nature 2008;453:1051-1057.

123. Carr TF, Kraft M. Chronic infection and severe asthma. Immunol Allergy Clin North Am 2016;36:483-502.

124. Kim YS, Choi JP, Kim MH, Park HK, Yang S, Kim YS, et al. IgG sensitization to extracellular vesicles in indoor dust is closely associated with the prevalence of non-eosinophilic asthma, COPD, and lung cancer. Allergy Asthma Immunol Res 2016;8:198-205.

125. Jeon SG, Moon HG, Kim YS, Choi JP, Shin TS, Hong SW, et al. 15-lipoxygenase metabolites play an important role in the development of a T-helper type 1 allergic inflammation induced by double-stranded RNA. Clin Exp Allergy 2009;39:908-917.

126. Jiménez-Ruiz CA, Andreas $S$, Lewis KE, Tonnesen $P$, van Schayck $C P$, Hajek $\mathrm{P}$, et al. Statement on smoking cessation in COPD and other pulmonary diseases and in smokers with comorbidities who find it difficult to quit. Eur Respir J 2015;46:61-79.

127. Telenga ED, Kerstjens HA, Ten Hacken NH, Postma DS, van den Berge $M$. Inflammation and corticosteroid responsiveness in ex-, currentand never-smoking asthmatics. BMC Pulm Med 2013;13:58. 
128. Thomson NC, Chaudhuri R, Heaney LG, Bucknall C, Niven RM, Brightling CE, et al. Clinical outcomes and inflammatory biomarkers in current smokers and exsmokers with severe asthma. J Allergy Clin Immunol 2013;131:1008-1016.

129. Adenuga D, Yao H, March TH, Seagrave J, Rahman I. Histone deacetylase 2 is phosphorylated, ubiquitinated, and degraded by cigarette smoke. Am J Respir Cell Mol Biol 2009;40:464-473.

130. Dye JA, Adler KB. Effects of cigarette smoke on epithelial cells of the respiratory tract. Thorax 1994;49:825-834.

131. Smelter DF, Sathish V, Thompson MA, Pabelick CM, Vassallo R, Prakash YS. Thymic stromal lymphopoietin in cigarette smoke-exposed human airway smooth muscle. J Immunol 2010;185:3035-3040.

132. Wang L, Joad JP, Zhong C, Pinkerton KE. Effects of environmental tobacco smoke exposure on pulmonary immune response in infant monkeys. J Allergy Clin Immunol 2008;122:400-406, 406.e1-5.

133. Demarche S, Schleich F, Henket M, Paulus V, Van Hees T, Louis R. Detailed analysis of sputum and systemic inflammation in asthma phenotypes: are paucigranulocytic asthmatics really noninflammatory? BMC Pulm Med 2016;16:46.

134. Lazaar AL, Panettieri RA Jr. Is airway remodeling clinically relevant in asthma? Am J Med 2003;115:652-659.

135. Grainge CL, Lau LC, Ward JA, Dulay V, Lahiff G, Wilson S, et al. Effect of bronchoconstriction on airway remodeling in asthma. $N$ Engl J Med 2011;364:2006-2015.

136. Panettieri RA Jr. Neutrophilic and pauci-immune phenotypes in severe asthma. Immunol Allergy Clin North Am 2016;36:569-579.

137. Iwamoto H, Yokoyama A, Shiota N, Shoda H, Haruta Y, Hattori N, et al. Tiotropium bromide is effective for severe asthma with noneosinophilic phenotype. Eur Respir J 2008;31:1379-1380.

138. Woodruff PG, Dolganov GM, Ferrando RE, Donnelly S, Hays SR, Solberg OD, et al.. Hyperplasia of smooth muscle in mild to moderate asthma without changes in cell size or gene expression. Am J Respir Crit Care Med 2004;169:1001-1006.

139. Panettieri RA Jr, Kotlikoff MI, Gerthoffer WT, Hershenson MB, Woodruff PG, Hall IP, et al.; National Heart, Lung, and Blood Institute. Airway smooth muscle in bronchial tone, inflammation, and remodeling: basic knowledge to clinical relevance. Am J Respir Crit Care Med 2008;177:248-252.

140. Panettieri RA Jr. Airway smooth muscle: an immunomodulatory cell. J Allergy Clin Immunol 2002;110:S269-S274.

141. Panettieri RA Jr. Bronchial thermoplasty: targeting structural cells in severe persistent asthma. Ann Am Thorac Soc 2015;12:1593-1594.

142. Al-Alwan A, Bates JH, Chapman DG, Kaminsky DA, DeSarno MJ, Ivin CG, et al. The nonallergic asthma of obesity: a matter of distal lung compliance. Am J Respir Crit Care Med 2014;189:1494-1502.

143. Scott HA, Gibson PG, Garg ML, Wood LG. Airway inflammation is augmented by obesity and fatty acids in asthma. Eur Respir $\mathrm{J} 2011 ; 38: 594-602$.

144. Ather JL, Chung M, Hoyt LR, Randall MJ, Georgsdottir A, Daphtary NA, et al. Weight loss decreases inherent and allergic methacholine hyperresponsiveness in mouse models of diet-induced obese asthma. Am J Respir Cell Mol Biol 2016;55:176-187.

145. Kim HY, Lee HJ, Chang YJ, Pichavant M, Shore SA, Fitzgerald KA, et al. Interleukin-17-producing innate lymphoid cells and the NLRP3 inflammasome facilitate obesity-associated airway hyperreactivity. Nat Med 2014;20:54-61.

146. Castro M, Zangrilli J, Wechsler ME, Bateman ED, Brusselle GG, Bardin $\mathrm{P}$, et al. Reslizumab for inadequately controlled asthma with elevated blood eosinophil counts: results from two multicentre, parallel, double-blind, randomised, placebo-controlled, phase 3 trials. Lancet Respir Med 2015;3:355-366.

147. Hanania NA, Noonan M, Corren J, Korenblat P, Zheng Y, Fischer SK, et al. Lebrikizumab in moderate-to-severe asthma: pooled data from two randomised placebo-controlled studies. Thorax 2015;70:748-756.

148. Cowan DC, Taylor DR, Peterson LE, Cowan JO, Palmay R, Williamson A, et al. Biomarker-based asthma phenotypes of corticosteroid response. J Allergy Clin Immunol 2015;135:877-883.e1.

149. Little SA, Chalmers GW, MacLeod KJ, McSharry C, Thomson NC. Non-invasive markers of airway inflammation as predictors of oral steroid responsiveness in asthma. Thorax 2000;55:232-234.
150. Wenzel S, Castro M, Corren J, Maspero J, Wang L, Zhang B, et al. Dupilumab efficacy and safety in adults with uncontrolled persistent asthma despite use of medium-to-high-dose inhaled corticosteroids plus a long-acting $\beta 2$ agonist: a randomised double-blind placebo-controlled pivotal phase $2 \mathrm{~b}$ dose-ranging trial. Lancet 2016;388:31-44.

151. Chakir J, Haj-Salem I, Gras D, Joubert P, Beaudoin ÈL, Biardel S, et al. Effects of bronchial thermoplasty on airway smooth muscle and collagen deposition in asthma. Ann Am Thorac Soc 2015;12:1612-1618.

152. Dente FL, Bacci E, Bartoli ML, Cianchetti S, Costa F, Di Franco A, et al. Effects of oral prednisone on sputum eosinophils and cytokines in patients with severe refractory asthma. Ann Allergy Asthma Immunol 2010;104:464-470.

153. FitzGerald JM, Bleecker ER, Nair P, Korn S, Ohta K, Lommatzsch M, et al.; investigators Cs. Benralizumab, an anti-interleukin- 5 receptor $\alpha$ monoclonal antibody, as add-on treatment for patients with severe, uncontrolled, eosinophilic asthma (CALIMA): a randomised, doubleblind, placebo-controlled phase 3 trial. Lancet 2016;388:2128-2141.

154. Normansell R, Walker S, Milan SJ, Walters EH, Nair P. Omalizumab for asthma in adults and children. Cochrane Database Syst Rev 2014;1: Cd003559.

155. Gonem S, Berair R, Singapuri A, Hartley R, Laurencin MF, Bacher G, et al. Fevipiprant, a prostaglandin $\mathrm{D} 2$ receptor 2 antagonist, in patients with persistent eosinophilic asthma: a single-centre, randomised, double-blind, parallel-group, placebo-controlled trial. Lancet Respir Med 2016;4:699-707.

156. Simpson JL, Powell H, Boyle MJ, Scott RJ, Gibson PG. Clarithromycin targets neutrophilic airway inflammation in refractory asthma. Am J Respir Crit Care Med 2008;177:148-155.

157. Brusselle GG, Vanderstichele $C$, Jordens $P$, Deman R, Slabbynck H, Ringoet $\mathrm{V}$, et al. Azithromycin for prevention of exacerbations in severe asthma (AZISAST): a multicentre randomised double-blind placebo-controlled trial. Thorax 2013;68:322-329.

158. Braganza G, Chaudhuri R, McSharry C, Weir CJ, Donnelly I, Jolly L, et al. Effects of short-term treatment with atorvastatin in smokers with asthma: a randomized controlled trial. BMC Pulm Med 2011; $11: 16$.

159. Spears M, Donnelly I, Jolly L, Brannigan M, Ito K, McSharry C, et al. Bronchodilatory effect of the PPAR-gamma agonist rosiglitazone in smokers with asthma. Clin Pharmacol Ther 2009;86:49-53.

160. Dixon AE, Subramanian M, DeSarno M, Black K, Lane L, Holguin F. A pilot randomized controlled trial of pioglitazone for the treatment of poorly controlled asthma in obesity. Respir Res 2015;16:143.

161. Spears M, Donnelly I, Jolly L, Brannigan M, Ito K, McSharry C, et al. Effect of low-dose theophylline plus beclometasone on lung function in smokers with asthma: a pilot study. Eur Respir J 2009;33:1010-1017.

162. Gauvreau GM, Boulet LP, Schmid-Wirlitsch C, Cote J, Duong M, Killian KJ, et al. Roflumilast attenuates allergen-induced inflammation in mild asthmatic subjects. Respir Res 2011;12:140.

163. Meltzer EO, Chervinsky P, Busse W, Ohta K, Bardin P, Bredenbroker $D$, et al. Roflumilast for asthma: efficacy findings in placebocontrolled studies. Pulm Pharmacol Ther 2015;35(Suppl):S20-S27.

164. Nair P, Gaga M, Zervas E, Alagha K, Hargreave FE, O'Byrne PM, et al. Safety and efficacy of a CXCR2 antagonist in patients with severe asthma and sputum neutrophils: a randomized, placebo-controlled clinical trial. Clin Exp Allergy 2012;42:1097-1103.

165. Busse WW, Holgate S, Kerwin E, Chon Y, Feng J, Lin J, et al. Randomized, double-blind, placebo-controlled study of brodalumab, a human anti-IL-17 receptor monoclonal antibody, in moderate to severe asthma. Am J Respir Crit Care Med 2013;188: 1294-1302.

166. Berry MA, Hargadon B, Shelley M, Parker D, Shaw DE, Green RH, et al. Evidence of a role of tumor necrosis factor alpha in refractory asthma. N Engl J Med 2006;354:697-708.

167. Holgate ST, Noonan M, Chanez P, Busse W, Dupont L, Pavord I, et al. Efficacy and safety of etanercept in moderate-to-severe asthma: a randomised, controlled trial. Eur Respir J 2011;37:1352-1359.

168. Wenzel SE, Barnes PJ, Bleecker ER, Bousquet J, Busse W, Dahlen $\mathrm{SE}$, et al. A randomized, double-blind, placebo-controlled study of tumor necrosis factor-alpha blockade in severe persistent asthma. Am J Respir Crit Care Med 2009;179:549-558. 